\title{
Recent advances in central congenital hypothyroidism
}

\author{
Nadia Schoenmakers, Kyriaki S Alatzoglou', V Krishna Chatterjee and Mehul T Dattani \\ University of Cambridge Metabolic Research Laboratories, Wellcome Trust-Medical Research Council Institute of \\ Metabolic Science, Addenbrooke's Hospital, Level 4, PO Box 289, Hills Road, Cambridge CB2 0QQ, UK \\ ${ }^{1}$ Developmental Endocrinology Research Group, Section of Genetics and Epigenetics in Health and Disease, \\ Genetics and Genomic Medicine Programme, UCL Institute of Child Health, London, UK
}

Correspondence

should be addressed

to N Schoenmakers

Email

naaa2@cam.ac.uk

\begin{abstract}
Central congenital hypothyroidism (CCH) may occur in isolation, or more frequently in combination with additional pituitary hormone deficits with or without associated extrapituitary abnormalities. Although uncommon, it may be more prevalent than previously thought, affecting up to 1:16 000 neonates in the Netherlands. Since TSH is not elevated, $\mathrm{CCH}$ will evade diagnosis in primary, TSH-based, $\mathrm{CH}$ screening programs and delayed detection may result in neurodevelopmental delay due to untreated neonatal hypothyroidism. Alternatively, coexisting growth hormones or ACTH deficiency may pose additional risks, such as life threatening hypoglycaemia. Genetic ascertainment is possible in a minority of cases and reveals mutations in genes controlling the TSH biosynthetic pathway (TSHB, TRHR, IGSF1) in isolated TSH deficiency, or early (HESX1, LHX3, LHX4, SOX3, OTX2) or late (PROP1, POU1F1) pituitary transcription factors in combined hormone deficits. Since TSH cannot be used as an indicator of euthyroidism, adequacy of treatment can be difficult to monitor due to a paucity of alternative biomarkers. This review will summarize the normal physiology of pituitary development and the hypothalamic-pituitary-thyroid axis, then describe known genetic causes of isolated central hypothyroidism and combined pituitary hormone deficits associated with TSH deficiency. Difficulties in diagnosis and management of these conditions will then be discussed.
\end{abstract}

\section{Introduction}

Central congenital hypothyroidism $(\mathrm{CCH})$ is a rare disorder in which inadequate thyroid hormone biosynthesis occurs due to defective stimulation of a normal thyroid gland by thyroid stimulating hormone (TSH). The underlying molecular basis is often undefined, but hypothalamic or pituitary pathology contributes to a qualitative or quantitative deficit in TSH synthesis or secretion (Persani 2012). In a minority of cases, TSH deficiency is isolated and may occur as a result of defects in genes controlling the TSH biosynthetic pathway, eg mutations in the thyrotropin-releasing hormone receptor
(TRHR), thyroid stimulating hormone $\beta$ subunit (TSHB) and the more recently-described immunoglobulin superfamily member 1 gene (IGSF1) (Garcia et al. 2014). Alternatively, as normal pituitary development depends on the sequential temporal and spatial expression of a cascade of signaling molecules and transcription factors, mutations in early (HESX1, LHX3, LHX4, SOX3, OTX2) or late (PROP1, POU1F1) transcription factors may cause central hypothyroidism with or without associated extrapituitary abnormalities. However, in these cases, central hypothyroidism does not occur in isolation, but is one of 
the evolving pituitary hormone deficiencies (Alatzoglou \& Dattani 2009, Kelberman et al. 2009).

Since TSH is not elevated in $\mathrm{CCH}$, this entity will evade diagnosis in TSH-based, primary $\mathrm{CH}$ screening programs, and patients are at risk of neurodevelopmental delay if severe $\mathrm{CCH}$ remains untreated postnatally. Additionally, the delayed diagnosis of other pituitary hormone deficiencies (Adrenocorticotrophic hormone; ACTH, growth hormone; GH) may pose significant risks, such as life threatening hypoglycaemia.

In spite of current knowledge regarding genetic causes of $\mathrm{CCH}$, the majority of cases do not have an identifiable molecular defect in known causative genes. This review will summarize our current understanding of the molecular genetics underlying $\mathrm{CCH}$ as well as highlighting controversies in treatment and diagnosis.

\section{Physiology/embryology}

\section{Morphogenesis and cellular differentiation in pituitary development}

The development of the anterior pituitary requires the sequential temporal and spatial expression of a cascade of signaling molecules and transcription factors that are important for organ commitment, cell proliferation, patterning and terminal differentiation. Human pituitary gland development in humans largely mirrors that in rodents (Sheng \& Westphal 1999) (Fig. 1). The anterior pituitary develops from the hypophyseal placode that appears ventrally in the midline of the anterior neural ridge at embryonic day (E) 7.5, and is in continuity with the future hypothalamo-infundibular region, which is located in the rostral part of the neural plate (Rizzoti \& Lovell-Badge 2005). By E8.5 the placode appears as a thickening of the roof of the primitive oral cavity and at E9.0, it invaginates to form the rudimentary Rathke's pouch, from which the anterior and intermediate lobes of the anterior pituitary are derived (Takuma et al. 1998, Rizzoti \& Lovell-Badge 2005). The definitive pouch is formed by E10.5, whilst the neural ectoderm at the base of the developing diencephalon evaginates to give rise to the posterior pituitary. The pouch epithelium continues to proliferate between E10.5 and E12 and separates from the underlying oral ectoderm at E12.5. The progenitors of the hormone-secreting cell types proliferate ventrally from the pouch between E12.5 and 17.5 to populate the future anterior lobe (Ward et al. 2005). Progenitor cells divide around the lumen of Rathke's pouch and relocate ventrally as they differentiate. This ventral relocalisation is associated with exit from the cell cycle (Drouin et al. 2010) and expression of cyclin-dependent kinase inhibitor 1C (p57Kip2) and cyclin E, at the boundary between the lumen and the forming anterior lobe (Bilodeau et al. 2009).

In the developing pituitary, there are two populations of thyrotrope cells: a transient population of rostral tip thyrotropes and the 'definitive' thyrotropes that will populate the anterior pituitary. The earliest marker of differentiation in the anterior pituitary is the expression by E11.5 of $\alpha \mathrm{GSU}$ (alpha-glycoprotein subunit; $C g a$ ) in a restricted patch of cells in the ventral region of Rathke's pouch. These $\alpha \mathrm{GSU}$ positive cells will express the transcription factor Islet-1 (Isl1) and will differentiate at E12.5 by initiating the expression of thyroid stimulating hormone subunit- $\beta$ (Tshb) (Ericson et al. 1998, Kelberman et al. 2009). This cell population, referred to as rostral tip thyrotropes, is POU1F1-independent and will disappear at birth (Himes \& Raetzman 2009). The definitive thyrotropes are detected later, at E14.5, after the appearance of corticotropes (that start to differentiate at E12.5), as defined by the expression of Pomc (Zhu et al. 2007, Kelberman et al. 2009). This cell population, referred to as 'thyrotropes', is POU1F1-dependent and will secrete functional TSH. In the adult pituitary gland, there are no rostral tip thyrotropes and the expression of $\alpha \mathrm{GSU}$ will only be detected in thyrotropes and gonadotropes (Ericson et al. 1998, Himes \& Raetzman 2009, Kelberman et al. 2009). The expression of $G H$ and Prolactin (Prl) by E15.5 is the hallmark of the differentiation of somatotrope and lactotrope lineages respectively. Whilst gonadotropes are the last cell type to emerge, beginning at E16.5 with the onset of luteinizing hormone (LH) subunit $\beta$ ( $L h b$ ) expression, followed by follicle-stimulating hormone (FSH) subunit $\beta$ (Fshb) a day later (Kelberman et al. 2009).

Although the classic description of cell differentiation is based on the sequential appearance of differentiating markers, recent birthdating studies imply that endocrine cells may be specified earlier and migrate some distance before they can be characterized by their differentiated markers. In fact, most of the hormone expressing cell types appear to differentiate between E11.5 and E13.5, denoting a broader range of specification rather than a sequential pattern of discrete times (Davis et al. 2011).

Concomitantly with these events, the hypothalamic primordium becomes morphologically evident in the neural ectoderm at E9.5 with neurogenesis commencing at E10, coinciding with the highest level of expression of genes important for the regional patterning of hypothalamic progenitor cells, such as $\operatorname{Sim} 1, \operatorname{Sim} 2, \operatorname{Arx}$

Published by Bioscientifica Ltd 


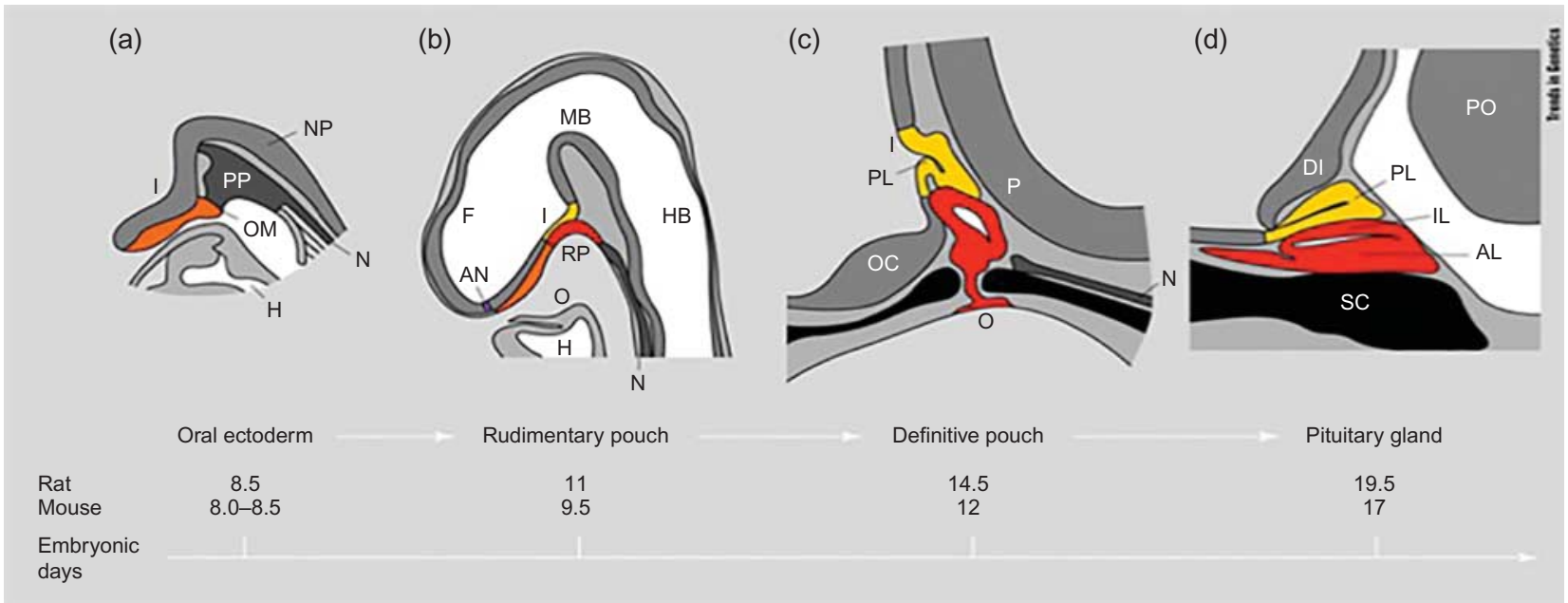

\section{Figure 1}

Schematic representation of the stages of pituitary development in rodents: (a) Oral ectoderm (b) Rudimentary pouch (c) Definitive pouch (d) Adult pituitary gland. The close contact between the developing Rathke's pouch (red) and the infundibulum (yellow) is maintained throughout and is important for the normal morphogenesis of the gland. I, infundibulum; $\mathrm{NP}$, neural plate; N, notochord; PP, pituitary placode; OM, oral membrane;

and Nr5a1 (Shimogori et al. 2010). Hypothalamic neurogenesis is complete by E16 although expression of hypothalamic terminal differentiation markers peak postnatally (Shimogori et al. 2010). In the developing murine hypothalamus, transcription factors including Gsh1, Mash1, Ash1, Sim1, Sim2, Arnt2, Brn-2, and Otp are important for the differentiation of the parvocellular neurons secreting the neuropeptides TRH, thyrotropinreleasing hormone; GHRH, growth-hormone releasing hormone; SST, somatostatin; CRH, corticotropin-releasing hormone (Shimogori et al. 2010, Diaz et al. 2015). In the developing rat, hypothalamus Trh cells first appear at E10.5 in the ventral part of the anterior paraventricular area $(\mathrm{VPa})$ and by E12.5 they are also found in the ventral portion of the paraventricular hypothalamic complex (TPVa) as well as in the central and dorsal portion of the peduncular paraventricular area (CPa and DPa) (Diaz et al. 2015). Recently, Trh expressing cells were also detected in the lateral hypothalamic area that is associated with behavioural response to motivation and metabolic stimuli (Horjales-Araujo et al. 2014).

\section{Genetic factors important for thyrotrope development}

Signalling molecules from the ventral diencephalon (Bmp4, Fgf8, Fgf4, Nkx2.1, Wnt5 $\alpha$ ), the oral ectoderm (Sonic Hedgehog, Shh), the surrounding mesenchyme (Bmp2, Chordin) and the pouch itself (Bmp2, Wnt4)
$H$, heart; $F$, forebrain; MB, midbrain; $H B$, hindbrain; RP, Rathke's pouch; $A N$, anterior neural pore; $\mathrm{O}$, oral cavity; $\mathrm{PL}$, posterior lobe; $\mathrm{OC}$, optic chiasm; $\mathrm{P}$, pontine flexure; PO, pons; IL, intermediate lobe; $\mathrm{AL}$, anterior lobe; $\mathrm{DI}$, diencephalon; SC, sphenoid cartilage. Reprinted from Trends in Genetics, volume 15 , Sheng $\mathrm{HZ}$, Westphal H, Early steps in pituitary organogenesis, pages 236-240, Copyright (1999), with permission from Elsevier. contribute to establish signalling gradients and the expression of transcription factors which will determine the positional identity of ventral pituitary cells (Zhu et al. 2007, Kelberman et al. 2009) (Fig. 2). Terminal differentiation of the anterior pituitary cell types is the result of complex interactions between extrinsic signalling molecules and transcription factors (HESX1, SOX2, SOX3, OTX2, LHX3, LXH4, GATA2, ISL1, PROP1, POU1F1) of which GATA2, PITX1/2, PROP1 and POU1F1 are most critical for the differentiation of thyrotropes.

Expression of Pitx 1 is first detected in the anterior ectoderm at E8.0, then expressed throughout the oral ectoderm and in Rathke's pouch by E 9.5, and maintained throughout anterior pituitary development in all hormone-producing cell types. In the adult pituitary, Pitx1 expression is highest in thyrotropes expressing $\alpha \mathrm{GSU}$ and in gonadotropes with lower levels in other hormoneproducing cell types (Lanctot et al. 1999). Pitx1 null embryos have normal pituitary morphogenesis; however, at birth the number of thyrotropes and gonadotropes are reduced. This absence of early defects may in part be explained by the redundant function of the closely related PITX2.

Expression of PITX2 is detected widely in Rathke's pouch and in the developing pituirary, whilst in adults it is expressed predominantly in thyrotropes and gonadotropes. Mice with targeted deletion of Pitx 2 in thyrotropes have smaller thyroid glands, upregulated levels of 


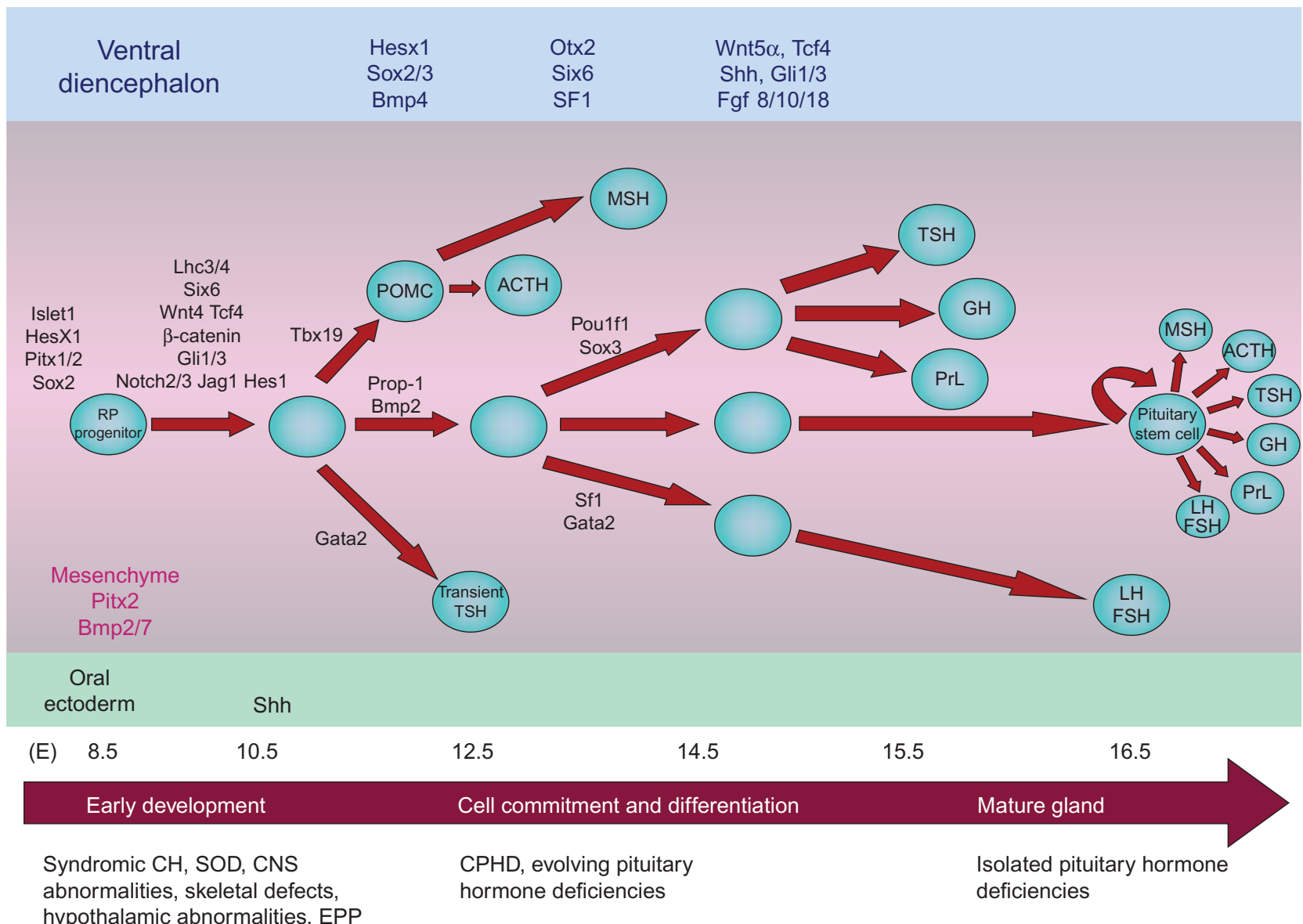

\section{Figure 2}

Schematic cascade of transcription factors and signaling molecule during pituitary development. Terminal differentiation of the anterior pituitary cell types is the result of complex interactions between extrinsic signalling molecules and transcription factors (HESX1, SOX2, SOX3, OTX2, LHX3, LXH4, GATA2, ISL1, PROP1, POU1F1). Possible pituitary phenotypes arising from mutations at different stages of pituitary development are indicated.
SOD, septo-optic dysplasia; CNS, central nervous system; EPP, ectopic posterior pituitary; CPHD, combined pituitary hormone deficiency. Reproduced, with permission, from Kelberman D, Rizzoti K, Lovell-Badge R, Robinson IC, Dattani MT 2009 Genetic regulation of pituitary gland development in human and mouse, Endocrine Reviews 30 790-829. Copyright (2009) The Endocrine Society. pituitary Pitx1 transcripts and circulating TSH and $\mathrm{T}_{4}$ in the normal range (Castinetti et al. 2011). In these animals, induction of hypothyroidism (by low iodine diet and oral propylthiouracil) results in a blunted TSH response. Although under these conditions control mice have significant increase in PITX1 transcripts, they remain unchanged in mutant animals (Castinetti et al. 2011).

Expression of Gata2 is first detected at E10.5 in the ventral Rathke's pouch, where it is induced by BMP2 along with $\alpha \mathrm{GSU}$, therefore marking the prospective and definitive thyrotropes and gonadotropes; its expression is maintained in the adult pituitary. In vitro GATA2 activates the $C g a$ promoter and acts synergistically with POU1F1 to induce expression of Tshb (Gordon et al. 2002). Ectopic expression of Gata2 under the control of the Pou1f1 promoter results in dorsal expansion of the gonadotrope population at the expense of the Pou1f1 lineage (somatotropes, lactotropes and thyrotropes). Therefore, GATA2 may be required for the specification of gonadotropes and thyrotropes both in opposition and in synergy with POU1F1 (Dasen et al. 1999).

Knock-out of GATA2 specifically in the pituitary results in mice with fewer thyrotropes at birth, that exhibit growth delay postnatally and produce less TSH in response to severe hypothyroidism, compared to WT animals. The population of thyrotropes is only transiently reduced in neonates. However, in adult animals, levels of circulating TSH remain low and the function of thyrotropes is abnormal. These Gata2-deficient mice have increased levels of Gata3 transcripts in the pituitary

Published by Bioscientifica Ltd 
gland, suggesting that the upregulation of GATA3 may have a compensatory role (Charles et al. 2006)

PROP1 (Prophet of PIT-1) is a pituitary-specific pairedlike homeodomain transcription factor initially detected in the dorsal portion of Rathke's pouch at E10-10.5; its expression peaks at E12 and becomes undetectable by E15.5 dpc (Kelberman et al. 2009). The onset of Prop1 expression is required for the emergence of the Pou1f1 lineage (somatotropes, lactotropes and thyrotropes), whilst its persistent expression delays the differentiation of gonadotropes (Cushman et al. 2001). In vitro PROP1 and $\beta$-catenin form a complex, along with other cofactors that directly repress Hesx1 while activating expression of Pou1f1 (Olson et al. 2006)

The Ames dwarf mouse, that has a naturally occurring Prop1 mutation resulting in an eight-fold reduction in DNA-binding activity, has severe proportional dwarfism and infertility with GH, TSH and PRL deficiency, and reduced gonadotropin expression correlating with low plasma LH and FSH. The anterior pituitary gland in these animals is reduced in size by about $50 \%$ with an abnormal looping appearance (Ward et al. 2005, Ward et al. 2006).

Pou1f1 is expressed relatively late during pituitary development and is detectable in prospective somatotropes, lactotropes, and thyrotropes from E13.5. It reaches maximum expression in differentiating GH, PRL, and TSH cells by E16 and its extression persists in adulthood (Kelberman et al. 2009). POU1F1 is required for the production of GH, PRL, and TSHB as well as the expression of GHRHR. Two naturally occurring recessive mouse mutants, the Snell and Jackson dwarf mouse, exhibit an identical phenotype with postnatal, but not embryonic, anterior pituitary hypoplasia and GH, TSH, and PRL deficiencies (Kelberman et al. 2009). POU1F1 is able to inhibit GATA2, independently of its DNA binding properties, to prevent gonadotrope fate, whereas in thyrotropes, POU1F1 and GATA2 act synergistically to promote the thyrotrope fate (Dasen et al. 1999).

\section{Control of TSH biosynthesis}

\section{The hypothalamic-pituitary-thyroid axis}

Positive regulation of thyroid hormone synthesis Circulating concentrations of $\mathrm{T}_{3}$ and $\mathrm{T}_{4}$ are maintained within a narrow range in vivo by a highly regulated balance of positive and negative feedback mediated by the hypothalamic-pituitary-thyroid (HPT) axis and centrally regulated by TRH (Fig. 3). TRH is synthesized as a prohormone in the paraventricular nucleus (PVN) of the hypothalamus and matures into the TRH tripeptide amide (pGlu-His-ProNH2) following post-translational cleavage by prohormone convertases PC1/3 and 2. After axonal transport to the median eminence, TRH reaches the thyrotrophs of the anterior pituitary gland via the hypothalamic portal vein, where it binds its G-protein coupled receptor, TRHR, and activates a Gq/11 dependent pathway involving mobilization of intracellular calcium and activation of protein kinase $\mathrm{C}$, culminating in TSH synthesis and secretion. Pyroglutamyl peptidase II (PPII) activity subsequently mediates degradation of extracellular TRH (Hinkle et al. 2012, Fekete \& Lechan 2014). Recent data suggests a role for the membrane glycoprotein IGSF1 in normal TRHR expression, although the precise function of IGSF1 remains unclear (Sun et al. 2012).

Besides upregulating transcription of the TSH alpha $(\alpha \mathrm{GSU})$ and $\beta$ subunit genes (CGA and TSHB), TRH mediates conjugation of TSH $\alpha$ and $\beta$ subunits and regulates glycosylation and secretion of heterodimeric TSH. Incorporation of oligosaccharide determines TSH bioactivity, which is principally defined by the type and conformation of carbohydrate chain added at Asn-76 and -102 of the $\alpha$ subunit and Asn- 43 on the $\beta$ subunit such that TSH with a high sialic acid content exhibits decreased bioactivity and increased half life. (Persani 1988, Estrada et al. 2014).

In the thyroid, TSH binds a G-protein coupled receptor, TSH-receptor (TSHR), stimulating follicular cell growth and thyroid hormone synthesis and release, predominantly in the form of the prohormone thyroxine $\left(\mathrm{T}_{4}\right)$. Deiodination of $\mathrm{T}_{4}$ in peripheral tissues yields the active hormone, 3,5, $3^{\prime}$-triodothyronine $\left(\mathrm{T}_{3}\right)$ which binds thyroid hormone receptors (TR's) to exert its transcriptional effects. TR isoforms TR $\alpha 1, \beta 1$, and $\beta 2$ exhibit tissuespecific expression patterns and heterodimerize with retinoid X receptor (RXR) on specific Thyroid Receptor DNA response elements (TREs), usually located in promoter regions of target genes. With upregulated genes, unliganded TRs mediate repression of basal gene transcription by binding the TRE together with other proteins, eg corepressors (NCOR1 and SMRT) and histone deacetylases (HDAC3) (Cheng et al. 2010). $\mathrm{T}_{3}$ binding results in a conformational change of the receptor ligandbinding domain, leading to coactivator recruitment, histone acetylation, relaxation of chromatin and transcriptional activation (Ortiga-Carvalho et al. 2014).

Negative regulation of thyroid hormone synthesis A classical negative feedback loop maintains circulating thyroid hormone levels within the normal range and is

Published by Bioscientifica Ltd 


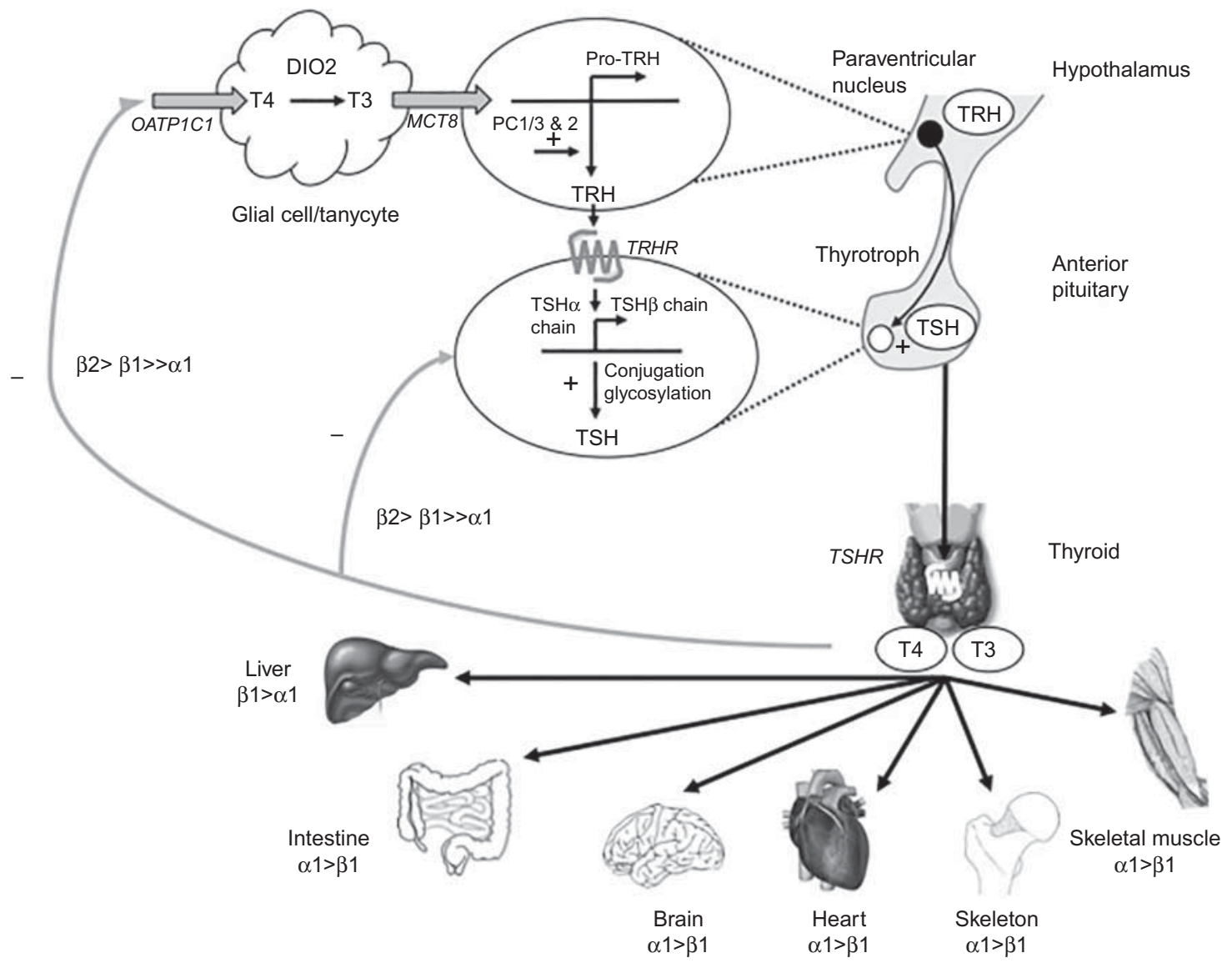

Figure 3

Diagramatic representation of the hypothalamic-pituitary-thyroid axis with positive regulation (black) predominantly mediated by thyrotropinreleasing hormone (TRH) and negative (grey) feedback influences, predominantly mediated by thyroid hormone receptor (TR) isoforms $\beta 2$ and $\beta 1$. Putative transporter molecules (grey) mediating these effects are

predominantly mediated by TR $\beta 2$ (Fig. 3). In the hypothalamus, thyroid hormone is taken up into the brain from cerebrospinal fluid (CSF) in the 3rd ventricle or from blood vessels in the median eminence by deiodinase type 2 (DIO2)-expressing tanycytes or astrocytes respectively. DIO2, converts $T_{4}$ to $T_{3}$ which then enters the TRH neurons and binds nuclear TR's. Intracellular delivery of thyroid hormones requires active transport, likely to be mediated by monocarboxylate transporter eight (MCT8) for uptake from tanycytes into neuronal cells and by organic anion-transporting polypeptide 1c1 (OATP1C1) for transport across the blood-brain barrier (Alkemade et al. 2011, Garcia et al. 2014, Alkemade 2015). A shorter $\mathrm{T}_{3}$-mediated negative feedback loop operates in the anterior pituitary, with the transport mechanism for pituitary thyroid hormone uptake remaining poorly defined. TSHR expression has also been demonstrated in annotated. OATP1C1 is expressed in capillaries throughout the brain, monocarboxyate transporter 8 (MCT8) is expressed in the PVN of the hypothalamus and in follicular stellate cells in the anterior pituitary (reviewed in Fliers et al. (2006)). Tissue-specific TR isoform expression is described, for thyroid hormone target tissues.

pituitary folliculostellate cells, leading to the suggestion that paracrine signaling in the pituitary may also contribute to negative feedback, but the mechanisms underlying this remain speculative (Prummel et al. 2004, Garcia et al. 2014).

In the hypothalamus, thyroid hormones downregulate transcription of the pro-TRH and PC1/3 and PC2 genes (Hollenberg et al. 1995, Perello et al. 2006) resulting in reduced levels of mature TRH. In the anterior pituitary, transcription of CGA and TSHB genes is inhibited (Shupnik et al. 1985, Wondisford et al. 1989, Wang et al. 2009). The mechanisms for negative regulation of transcription by TRs remain poorly understood (Ortiga-Carvalho et al. 2014) but may involve recruitment of corepressors instead of coactivators, eg Ncor1 during transcriptional repression of murine Cga, (You et al. 2010) Trans-repression, where liganded TR's interact with and inhibit the activity of other 
transcription factors, has also been implicated, eg GATA2 during TR-mediated repression of TSHB (Matsushita et al. 2007, Santos et al. 2011).

Additional modulators of TSH secretion include hypothalamic dopamine and somatostatin (inhibitory), and the influence of feeding behaviour, glucocorticoids, severe illness, cold, and circadian rhythm (Fliers et al. 2006).

\section{Genetic causes of central congenital hypothyroidism}

Isolated central hypothyroidism is a rare entity, with an estimated incidence of 1:65 000 and known genetic causes affect the TSH biosynthetic pathway, comprising mutations in TSHB and TRHR, and IGSF1 (Joustra et al. 2013a). In the majority of patients, CCH occurs in the context of combined pituitary hormone deficiencies, and additional syndromic features may manifest depending on its genetic aetiology. Only a minority of individuals will harbour mutations in known transcription factors such as POU1F1, PROP1, HESX1, LHX3, LHX4, SOX3 and OTX2 that are implicated in pituitary development (Alatzoglou \& Dattani 2009, Kelberman et al. 2009). This suggests that other, as yet unidentified genetic or epigenetic factors, may be implicated in the aetiology of $\mathrm{CCH}$.

\section{Isolated central congenital hypothyroidism}

\section{TSHB mutations}

Biallelic loss of function, TSHB mutations are associated with severe central hypothyroidism of neonatal onset for which additional biochemical hallmarks include elevated pituitary glycoprotein $\alpha$ subunit, and an impaired TSH response to TRH administration, despite a preserved rise in serum Prolactin (Bonomi et al. 2001) (Table 1). Concomitant neurodevelopmental impairment is a frequent finding, and usually correlates with treatment delay due to the fact that individuals evade detection on TSH-based, primary $\mathrm{CH}$ screening programmes, and remain undiagnosed until their profound congenital hypothyroidism manifests clinically. In cases who are diagnosed and treated from birth due to ascertainment following a prior genetic diagnosis in their family, developmental outcome is often improved (Brumm et al. 2002, Karges et al. 2004).

Heterodimeric TSH comprises the common $\alpha$ subunit $(\alpha \mathrm{GSU})$ shared with other glycoprotein hormone (LH, FSH, CG) family members and a hormone-specific $\beta$-subunit (TSHB) in which naturally-occurring mutations either truncate the protein, or perturb key structural features required for heterodimeric integrity (Fig. 4). In common with other cysteine-knot proteins, a central cysteine knot in each subunit is surrounded by two $\beta$-hairpin loops on one side, and a long loop on the other. A 'seat belt' formed from the TSH $\beta$ subunit, wraps around the long loop of the $\alpha$-subunit and forms an intra-molecular disulfide 'buckle' to stabilize the heterodimer and additional $\alpha-\beta$ subunit interactions occur around a conserved CAGYC sequence motif (Szkudlinski et al. 2002, Jiang et al. 2014). Conserved cysteine residues in all glycoprotein hormone $\beta$-subunits form disulphide bridges central to the three-dimensional structure of the protein, and alignment with $\beta$-hCG, for which the crystal structure has been solved, predicts similar interactions in TSHB. Disulphide bridges between Cys22-Cys72, Cys47-Cys103, and Cys51-Cys105 are thought to maintain the cystine-knot motif; Cys39Cys125 and Cys108-Cys115 are thought to be integral to 'seatbelt' formation; and an interaction between Cys37Cys87 is thought to link the two $\beta$-hairpin loops (Szkudlinski et al. 2002, Jiang et al. 2014).

Nine, naturally-occurring, TSHB mutations have been described, including missense (C108Y, C105R, G49R), nonsense and frameshift mutations (p.E32*, p.Q69*, p.C125Vfs*10, p.F77Sfs*6) (Hayashizaki et al. 1989, Dacou-Voutetakis et al. 1990, Medeiros-Neto et al. 1996, Bonomi et al. 2001, Vuissoz et al. 2001, Sertedaki et al. 2002, Morales et al. 2004, Baquedano et al. 2010), as well as two splice-site mutations (c162G>A, c.162+5 G>A) (Pohlenz et al. 2002, Baquedano et al. 2010). More recently, a homozygous TSHB deletion was reported (Hermanns et al. 2014). All the missense mutations disrupt key disulphide bridges required for heterodimeric integrity or disrupt the CAGYC region (Fig. 4). (For the purposes of this review, the nomenclature of these mutations follows the most recent HGNC guidelines to include the 20 amino acid signal peptide of TSHB, such that the annotation may differ from that cited in the original published articles.)

The most frequently described mutation is a single nucleotide deletion (c373delT) leading to a cysteine 125 to valine change (p.C125V) and subsequent frameshift and premature stop codon at position 134 (p.C125Vfs*10) (Medeiros-Neto et al. 1996). This has been reported worldwide in several, non-consanguineous families, although a founder effect was also described in three German kindreds (McDermott et al. 2002, Brumm et al. 2002, Deladoey et al. 2003, Domene et al. 2004, Karges et al. 2004). Functional studies have demonstrated that replacement of the cysteine at position 125 with valine, rather than subsequent deletion of the terminal 13 amino acids, impairs the bioactivity of the mutant TSH, by

Published by Bioscientifica Ltd 


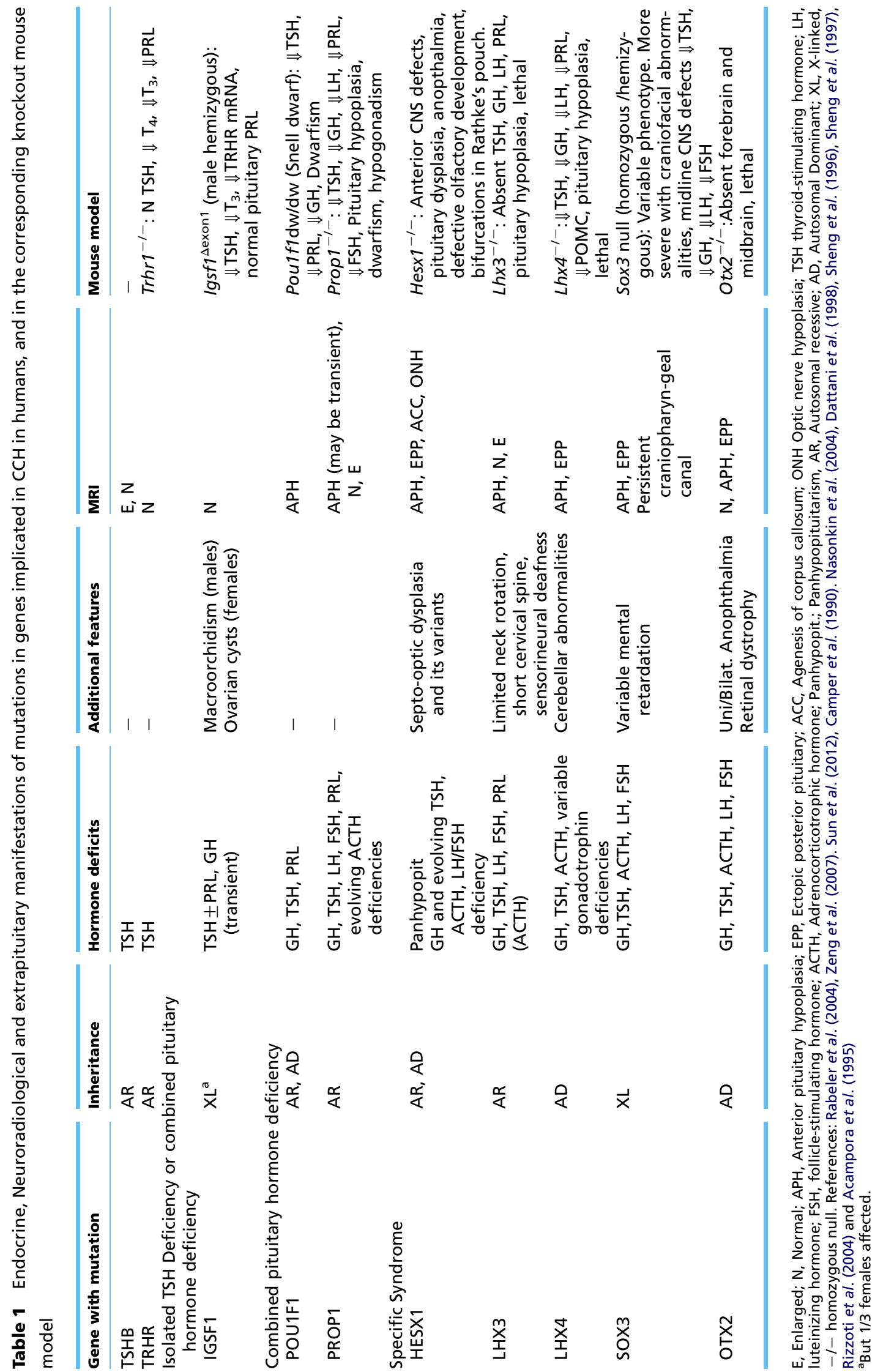




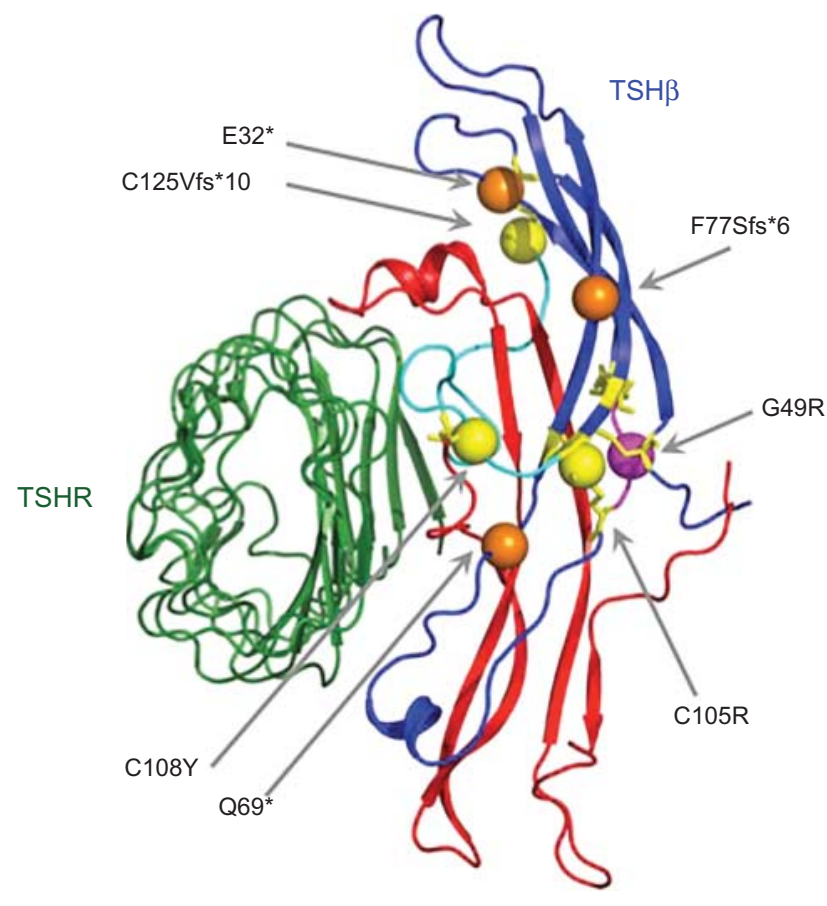

$\mathrm{TSH} \alpha$

\section{Figure 4}

Model for heterodimeric thyroid stimulating hormone (TSH) bound to the TSH receptor (TSHR) illustrating the position of naturally occurring TSHB loss-of-function mutations associated with congenital central hypothyroidism. The model was generated using PHYRE for predicting TSHbeta subunit $(\mathrm{TSH})$ structure and was modelled onto FSH-FSHR $(1 \times w d)$ and the TSHR-K1-7OFAB $(2 \times w t)$ structure using PYMOL. Colour coding is as follows: Green TSHR, Red: TSH alpha subunit (TSHa, aGSU), Blue: TSHb. Specific structural features required to maintain the heterodimeric structure: Cyan 'seatbelt' region, Yellow: cysteines conserved throughout cysteine knot proteins and involved in disulphide bridge formation. Spheres denote TSHB mutations: C105R; C108Y; C125Vfs*10 (yellow) disrupt disulphide bridges, G49R (purple) is located in the conserved CAGYC region and E32*; Q69*; F77Sfs*6 (orange) truncate the protein prematurely. The nomenclature of these mutations follows the most recent HGNC guidelines to include the 20 amino acid signal peptide of TSHB, thus may differ from that cited in the original articles. Nomenclature can be converted to that previously published for missense mutations by subtracting 20 eg Q69* new nomenclature $=\mathrm{Q} 49 \mathrm{X}$ old nomenclature.

disrupting the Cys125-Cys39 disulphide bond which forms the 'buckle' of the TSHB 'seatbelt' surrounding the alpha subunit (Medeiros-Neto et al. 1996).

Mutations (p.G49R, p.Q32*), which disrupt heterodimer formation between $\mathrm{TSH} \alpha$ and $\beta$ polypeptides generally result in unmeasurable serum TSH concentrations, whereas mutations (eg p.Q69*, IVS2+5 G>A, c.373delT), which preserve formation of some mutant, heterodimeric TSH expressing the epitopes recognized by the anti-TSH monoclonal antibody, enables TSH to be detected in an immunoassay-dependent manner. Thus, some cases may have detectable levels of immunoreactive TSH, but these species will lack normal bioactivity (Bonomi et al. 2001). In contrast, a recent report describes a TSHB variant with impaired immunoreactivity but normal bioactivity (c.223A $>$ G, p.R75G including the signal peptide). Two clinically euthyroid siblings, both homozygous for the variant, exhibited normal thyroid hormone levels but undetectable TSH specifically in Siemens assay platforms, due to poor TSH adsorption by the monoclonal antibody (Pappa et al. 2015). Although affected individuals are euthyroid, this variant had previously been detected in South East Asian patients, some of whom had consequently been inappropriately treated with antithyroid drugs (Drees et al. 2014). Alternatively, the undetectable TSH may erroneously suggest central hypothyroidism on $\mathrm{CH}$ screening.

\section{TRHR mutations}

Biallelic TRHR mutations are the least common cause of isolated congenital hypothyroidism, and have hitherto been described in only three cases from two unrelated kindreds. In both families, the male Probands exhibited subnormal $\mathrm{T}_{4}$ concentrations $40 \%$ to $88 \%$ lower limit of the normal range, with associated clinical manifestations predominantly comprising growth retardation and a delayed bone age. There was reportedly no attributable neurological deficit despite presentation of patients at age 9 and 11 years, suggesting preservation of sufficient thyroid hormone production in infancy to prevent overt mental retardation. Pituitary TSH synthesis was inadequate (in conjunction with low $\mathrm{T}_{4}$, serum TSH was inappropriately normal), but circulating $\mathrm{T}_{4}$ levels rose appropriately following levothyroxine withdrawal, indicating that synthesis of bioactive TSH could occur in the absence of TRH signalling (Collu et al. 1997, Bonomi et al. 2009). Rhythmic TSH secretion was also preserved and pituitary morphology was normal (Collu et al. 1997, Bonomi et al. 2009).

Intriguingly, a female with a homozygous, nonsense TRHR mutation (p.R17*), was only diagnosed with central hypothyroidism following family screening at the age of 33 , having previously achieved two normal pregnancies with subsequent lactation. Although TRHR is expressed in lactotrophs as well as thyrotrophs, and stimulates prolactin secretion in response to i.v. TRH administration, its physiological role in these cells is unclear. Both male and female individuals with biallelic TRHR mutations had absent TSH and prolactin responses to TRH administration. However, the obstetric history in the p.R17*

Published by Bioscientifica Ltd 
homozygous female suggests that TRH action is not obligatory for pregnancy and lactation in humans (Bonomi et al. 2009).

In common with all family A G-protein-coupled receptors (GPCR's), the structure of TRHR includes an extracellular $\mathrm{N}$-terminus and intracellular C-terminus, flanking seven transmembrane domains connected by three intracellular and three extracellular loops, which form a ligand-binding pocket within the plasma membrane. TRH-binding results in a conformational change involving transmembrane helices 5 and 6 and the third intracellular loop, with subsequent carboxyterminal domain-mediated G-protein coupling (Hinkle et al. 2012) (Fig. 5). In both families with TRHR defects, the mutations have been highly deleterious, resulting in complete abrogation of TRHR function. The first case was compound heterozygous for a maternally-inherited nonsense mutation (p.R17*) truncating the protein before the transmembrane domains, and a paternally-inherited in-frame deletion of three amino acids (S115, I116, and T117) with one substitution (p.A118T) in the third

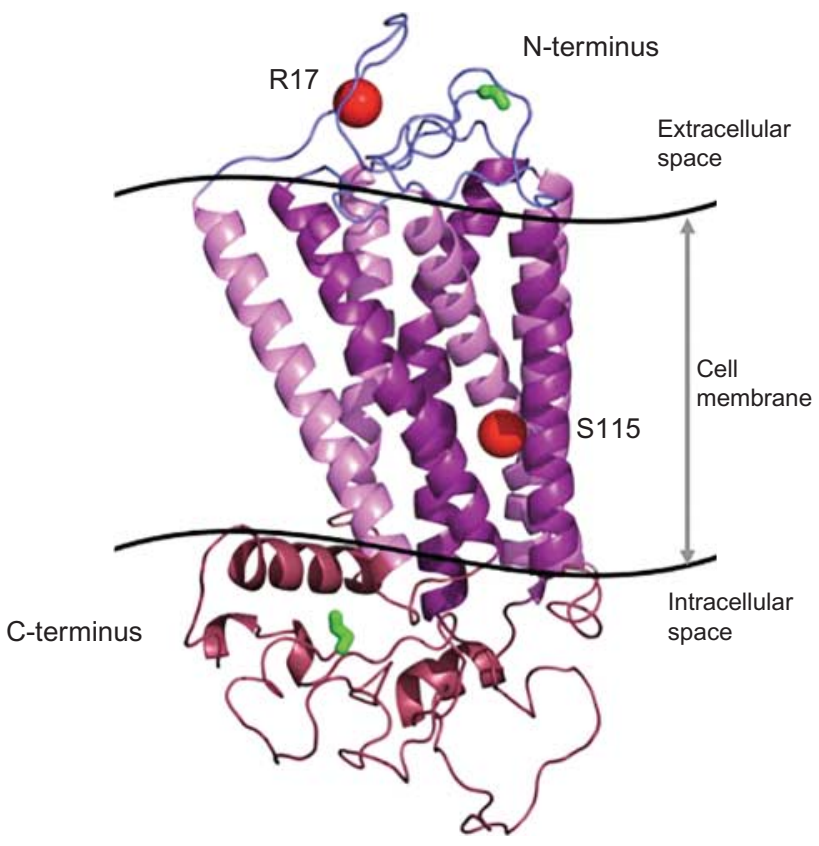

Figure 5

Crystallographic modeling of TRHR showing the positions (red spheres) of the two previously described mutations associated with central hypothyroidism: R17X truncating the protein in the extracaellular domain and an in-frame deletion of 3 amino acids (Ser115-Thr117) plus a missense change (Ala118 for Thr118; p.S115-T117del+T118) located at the cytoplasmic end of the third transmembrane domain of the receptor The TRHR structural model was generated by homology modeling using the PHYRE server and Pymol. The $\mathrm{N}$-terminal start codon and C-terminal end codon are highlighted in green. transmembrane domain. In the second reported kindred, affected individuals were homozygous for the p.R17* mutation (Collu et al. 1997, Bonomi et al. 2009) (Fig. 4).

Endocrine abnormalities in TRHR null humans are recapitulated in mice lacking Trhr1 who also exhibit subnormal $\mathrm{T}_{4}$ and $\mathrm{T}_{3}$ levels with inappropriately normal TSH (Table 1). Normal somatotrope, thyrotrope, and lactotrope numbers confirm that TRHR is not needed for the development or maintenance of TRH target cells, with preservation of fertility, pregnancy and lactation in females although both basal serum prolactin and lactation-stimulated prolactin mRNA are decreased. Increased fasting glucose concentrations were also observed in the mice. However, there is currently no evidence for an extrapituitary phenotype in humans with TRHR mutations (Rabeler et al. 2004, Zeng et al. 2007).

\section{IGSF1 mutations}

Mutations in the immunoglobulin superfamily member 1 (IGSF1) gene are the most recently identified cause of central hypothyroidism, with an estimated incidence of up to 1:100 000 (Sun et al. 2012, Joustra et al. 2013a). The X chromosome located IGSF1 gene encodes a membrane glycoprotein which was first thought to be an inhibin co-receptor in the pituitary, but recent binding and in vivo data from mice and humans suggests that this is unlikely (Chong et al. 2000, Chapman \& Woodruff 2001, Chapman et al. 2002, Bernard et al. 2003). At mRNA level, IGSF1 and its murine homolog Igsf1 are abundantly expressed in Rathke's pouch (the developing pituitary primordium) and in adult pituitary gland (Sun et al. 2012). A paucity of reliable antibodies has hampered expression studies of the human protein; however, in murine pituitary, IGSF1 protein is detected in thyrotropes, somatotropes and lactotropes, but not gonadotropes, and in the rat, pituitary expression is also confined to cells of the Pou1f1 lineage (Sun et al. 2012, Joustra et al. 2015a). Although a role for IGSF1 in pituitary and hypothalamic physiology is supported both by its cellular expression pattern and by endocrine consequences of IGSF1 deficiency in mice and humans, its precise physiological function in both species remains undefined (Sun et al. 2012).

The IGSF1 protein undergoes co-translational proteolysis such that the carboxyterminal portion trafficks to the plasma membrane where it is expressed as a large extracellular domain with a short intracellular cytoplasmic tail (Robakis et al. 2008). Fourteen pathogenic mutations in the IGSF1 gene have been described, in cases from the Netherlands, the UK, Italy and Japan (Sun et al.

Published by Bioscientifica Ltd 
2012, Nakamura et al. 2013, Tajima et al. 2013), all of which impair either protein maturation or membrane trafficking, resulting in decreased plasma membrane expression of IGSF1. The twelve missense or truncating mutations are all located in the extracellular portion of the carboxyterminal domain; the remaining two mutations are whole gene deletions (Fig. 6).

Four publications have documented the consequences of loss of function mutations in IGSF1 in humans (Sun et al. 2012, Joustra et al. 2013b, Nakamura et al. 2013, Tajima et al. 2013). All affected males exhibited central hypothyroidism, either isolated, or associated with hypoprolactinaemia (subnormal basal prolactin levels) (67\% cases). A minority of patients required treatment for transient, partial, growth hormone deficiency in childhood; paradoxically, in some European cases, circulating IGF1 levels tended to increase with age relative to the agematched reference interval and several patients developed acromegaloid features in late adulthood. Pubertal development was usually disharmonious, with a delayed pubertal growth spurt and testosterone rise despite normal onset of testicular growth. All evaluable European males subsequently developed adult macroorchidism, with ultrasonographic testicular volumes close to $50 \mathrm{ml}$ in two cases (Sun et al. 2012, Joustra et al. 2013b). Additionally, phenotyping of female IGSF1 mutation carriers indicated that although IGSF1 deficiency is X-linked, one-third of heterozygous females exhibit central hypothyroidism, and up to $11 \%$ demonstrate hypoprolactinaemia. Intriguingly, four of 18 females investigated had undergone surgical resection of benign ovarian cysts, suggesting possible shared pathogenetic mechanisms with the macroorchidism observed in males (Table 1). Skewed $\mathrm{X}$ inactivation was not a reliable predictor of endocrinopathy in female cases (Joustra et al. 2013b).

Murine studies have suggested that impaired TRH signaling may play a role in the central hypothyroidism associated with IGSF1 deficiency. Male igsf1 deficient mice are centrally hypothyroid, with decreased TRHR mRNA expression in the pituitary. In keeping with impaired TRH signaling, serum $\mathrm{T}_{3}$ and TSH levels are subnormal despite normal pituitary TSHB mRNA synthesis; and there is a blunted TSH response to TRH administration. Hypothalamic TRH mRNA levels are elevated, suggesting intact synthesis of TRH (Bernard et al. 2003, Sun et al. 2012) (Table 1). Most humans with hemizygous IGSF1 mutations exhibit biochemical hypothyroidism that is comparable to biallelic TRHR mutation cases, comprising mild-moderate $\mathrm{CCH}$ with detectable TSH and apparently normal neurological development even when the diagnosis is delayed until adulthood. These features would be consistent with impaired TRH signaling being the basis of the central hypothyroidism phenotype in the human IGSF1 deficiency, with such defective signaling also predicted to result in decreased bioactivity of TSH. Such qualitative assessment of TSH, either directly or indirectly

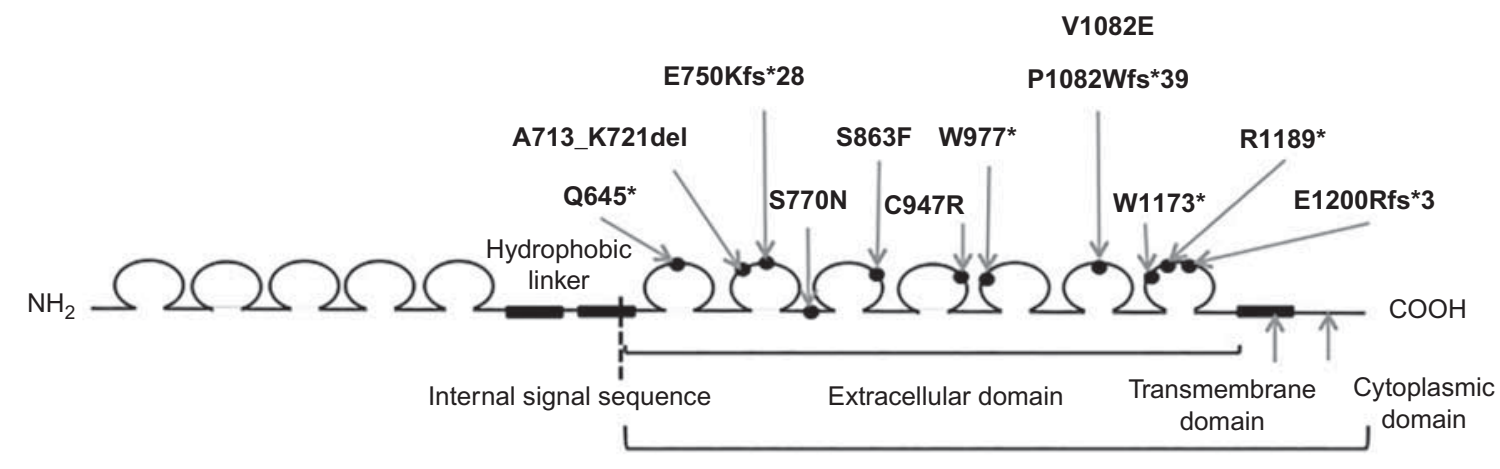

IGSF1-carboxyterminal domain

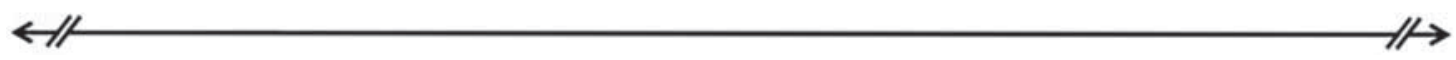

126- and 328-kb deletions

\section{Figure 6}

Schematic illustrating the protein domain structure of IGSF1 with the internal signal peptide directing cleavage of the carboxy-terminal domain denoted by a dashed line. Positions of naturally-occurring mutations associated with congenital central hypothyroidism are denoted; all are located within the carboxyterminal domain. Two whole gene deletions (below) have also been reported (Sun et al. 2012, Nakamura et al. 2013, Tajima et al. 2013). http://joe.endocrinology-journals.org DOI: $10.1530 / \mathrm{JOE}-15-0341$
(C) 2015 The authors Printed in Great Britain
Published by Bioscientifica Ltd 
by measurement of rise in circulating $\mathrm{T}_{3}$ and $\mathrm{T}_{4}$ increment during a prolonged TRH stimulation test, would therefore be informative in this context (Yamada \& Mori 2008).

The mechanisms underlying the macroorchidism and disharmonious pubertal development seen in IGSF1 deficient males remain to be ascertained, and mechanistic possibilities remain speculative. Excess hypothalamic TRH, acting on gonadotropes which express TRHR but not IGSF1, could drive macroorchidism via an FSHmediated process, consistent with observations that serum FSH was always higher than serum LH, in IGSF1deficient males (Kugler \& Huseman 1983, Ryan et al. 2007, Sun et al. 2012). Alternative contributory factors could include hypothyroxinaemia acting directly to increase Sertoli cell number and potentially also underlying the delayed testosterone rise (Weber et al. 2003, Holsberger \& Cooke 2005, Joustra et al. 2013a), although the absence of macroorchidism in other forms of congenital central hypothyroidism argues against this as the sole cause. A further possibility would be a direct testicular effect of IGSF1, but it remains unclear whether IGSF1 protein is expressed in human testis. Rats exhibit testicular expression of IGSF1 in adult Sertoli cells during stages XIII through VI of the seminiferous epithelium, and in elongating spermatids during epithelial stages $\mathrm{X}$ through XIII (Joustra et al. 2015a). IGSF1 deficient mice exhibit greater testicular weight but this is proportional to their increased body mass, and they do not express IGSF1 protein in testis (Sun et al. 2012).

Hitherto, studies of the endocrine effects of IGSF1 deficiency may been confounded by selection bias, with gene screening being undertaken predominantly in cases of central hypothyroidism. More recently, IGSF1 has been sequenced in euthyroid patients with X-linked constitutional delay of growth and puberty, and individuals with gigantism or acromegaly, with no evidence for a primary causative role for genetic variation in IGSF1 in these disorders (Faucz et al. 2015, Joustra et al. 2015b).

IGSF1 remains a highly polymorphic gene with an as yet incompletely characterized role both in anterior pituitary cells of the POU1F1 lineage, and in pubertal and gonadal development. Additionally, significant phenotypic variability amongst individuals harbouring IGSF1 mutations, suggests that its role may be influenced by as yet unidentified genetic or environmental modifiers.

\section{Combined pituitary hormone deficiencies}

Central congenital hypothyroidism in association with combined pituitary hormone deficiencies may be i) syndromic, resulting from mutations in early transcription factors, and associated with developmental abnormalities (eg septo-optic dysplasia and its variants, holoprosencephaly and midline defects, ocular or skeletal defects, and intellectual impairment) or ii) non syndromic resulting from mutations in late transcription factors (PROP1, POU1F1). The variable phenotypes, associations and MRI findings are summarized in Table 1.

Septo-optic dysplasia (SOD) is defined by the combination of two of the following i) optic nerve hypoplasia $(\mathrm{ONH})$ ii) midline forebrain defects (ie agenesis of the corpus callosum, absent septum pellucidum) and iii) pituitary hypoplasia with variable hypopituitarism. The commonest endocrine defect is GH deficiency followed by TSH and ACTH deficiency, whilst gonadotropin secretion may be retained. Mutations in HESX1, OTX2, and SOX3 have been identified in patients with TSH deficiency and SOD (Dattani et al. 1999, Woods et al. 2005, McNay et al. 2007). There is increasing evidence of overlap in the aetiology of conditions that were previously considered to be discrete, such as Kallmann syndrome, SOD and combined pituitary hormone deficiencies as mutations in the same array of genes (KAL-1, PROKR2, FGF8, FGFR1) have now been implicated in their aetiology. In this respect, the TSH deficiency may be part of the initial presentation or evolving phenotype of these patients (McCabe et al. 2011, McCabe et al. 2013).

Mutations in the Lim homeodomain transcription factors ( $L H X 3, L H X 4)$ lead to multiple pituitary hormone deficiencies, including TSH deficiency. Expression of $\operatorname{Lh} \times 3$ is initially detected uniformly within Rathke's pouch from E9.5 and by E16.5 it is expressed in the developing anterior and intermediate pituitary where its expression persists into adulthood. Mice with a targeted homozygous disruption of $L h \times 3$ die shortly after birth and exhibit pituitary aplasia. Although Rathke's pouch is initially formed, its expansion is arrested by E12.5 and lacks almost all of the hormone-secreting cell types, containing only a small population of corticotropes (Mullen et al. 2007, Kelberman et al. 2009). Patients with homozygous or compound heterozygous LHX3 mutations have an evolving endocrine phenotype involving GH, PRL, LH, FSH and TSH deficiency (Mullen et al. 2007). Although ACTH seems to be spared in the majority of patients, ACTH deficiency has also been described (Rajab et al. 2008). The anterior pituitary morphology is variable (hypoplastic, enlarged or presence of microadenoma) with a eutopic posterior pituitary. Patients may have cervical abnormalities, with or without restricted neck rotation,

Published by Bioscientifica Ltd 
sensorineural hearing loss (Netchine et al. 2000, Mullen et al. 2007).

$\operatorname{Lh} \times 4$ is closely related to $\operatorname{Lh} \times 3$; it is initially expressed throughout the Rathke's pouch at E9.5. However, in contrast to $L h x 3$, its expression is transient, restricted to the future anterior lobe and down-regulated by E12.5. Homozygous Lhx 4 null mice die shortly after birth from lung defects; the anterior lobe of Lhx $4^{-1-}$ mice contains all of differentiated cell types but there is reduction in cell proliferation (Mullen et al. 2007, Kelberman et al. 2009). Patients with heterozygous missense or frameshift LHX4 mutations have GH and variable gonadotrophin, TSH and ACTH deficiencies, a hypoplastic anterior pituitary with/ without an undescended/ectopic posterior pituitary and other abnormalities including a poorly formed sella turcica, pointed cerebellar tonsils or Chiari malformation (Castinetti et al. 2008, Pfaeffle et al. 2008)

Mutations in the transcriptional repressor HESX1 are associated with SOD, CPHD and IGHD (Dattani et al. 1998, Carvalho et al. 2003, McNay et al. 2007, Kelberman et al. 2009). Endocrine deficits may include GH, TSH, ACTH and gonadotrophin deficiencies. The anterior pituitary may be hypoplastic or absent whereas the posterior pituitary is usually ectopic but occasionally may be eutopic. In mice, Hes $x 1$ is expressed in the anterior neural ectoderm, and thereafter in the forebrain and developing pituitary, although its expression is switched off in the forebrain at E9, and in Rathke's pouch after E13.5. Homozygous null mutant mice have severe eye, forebrain and pituitary defects (Dattani et al. 1998, Sajedi et al. 2008), a phenotype that is reminiscent of SOD.

OTX2 (Orthodentic homeobox 2) is a transcription factor required for the formation of anterior structures and maintenance of the forebrain and has been implicated in $2-3 \%$ of anophthalmia/microphthalmia syndromes in humans (Boncinelli \& Morgan 2001, Kurokawa et al. 2004). In mice, the expression of Otx 2 is localised to developing brain, eye, nose and ear. Homozygous knockout mice die at midgestation with severe brain abnormalities, whereas heterozygous mutants have a variable phenotype ranging from normal to severe eye and brain abnormalities (anophthalmia, holoprosencephaly or anencephaly) (Acampora et al. 1995). Heterozygous mutations in OTX2 have highly variable pituitary phenotypes that range from partial IGHD to hypopituitarism, with or without an ectopic posterior pituitary and, rarely, even without an ocular phenotype (Dateki et al. 2008, Diaczok et al. 2008, Tajima et al. 2009).

Over- and under-dosage of SOX3 has been implicated in the aetiology of X-linked hypopituitarism with a highly variable phenotype ranging from isolated growth hormone deficiency to combined pituitary hormone deficiency, including evolving TSH deficiency, with or without variable mental retardation or learning difficulties. (Laumonnier et al. 2002, Woods et al. 2005, Alatzoglou \& Dattani 2009). MRI findings include an undescended posterior pituitary, anterior pituitary hypoplasia, or persistence of the craniopharyngeal canal (Woods et al. 2005, Alatzoglou et al. 2014).

PROP1 mutations are the most common cause of $\mathrm{CPHD}$, including $\mathrm{GH}$, TSH, gonadotropin, and evolving ACTH deficiencies of variable onset. Recessive PROP1 mutations are associated with $\mathrm{GH}$, TSH, prolactin and gonadotropin deficiency, although the timing and extent of these deficits vary and the full phenotype may not be evident from the outset. For instance, patients homozygous for the p.R120C mutation may first present in childhood with GHD before the later development of TSH, prolactin and gonadotropin deficiencies (Fluck et al. 1998). Most patients with PROP1 mutations have a hypoplastic or normal anterior pituitary gland with a eutopic posterior pituitary. However, there have been reports of an enlarged anterior pituitary at initial scanning in childhood with spontaneous involution over time, often waxing and waning before eventual involution (Voutetakis et al. 2004, Turton et al. 2005).

Patients with autosomal recessive and dominant POU1F1 mutations have GH and PRL deficiencies, that are generally present from early life, and are associated with a normal or hypoplastic anterior pituitary, whilst TSH deficiency can be highly variable. Although the majority have early TSH deficiency, hypothyroidism may also occur later in childhood. A patient with a POU1F1 mutation identical to that found in an unrelated patient who developed central hypothyroidism in the second year of life, has been reported with GH and PRL deficiency and yet normal thyroid function at the age of 21 years. (Turton et al. 2005).

\section{Diagnosis of central congenital hypothroidism}

The TSH-based protocol used by most neonatal $\mathrm{CH}$ screening programmes will unfortunately only detect primary $\mathrm{CH}$ since $\mathrm{CCH}$ is usually associated with inappropriately normal or low TSH. However, the merits of screening for $\mathrm{CCH}$ remain a subject of debate with arguments against screening citing its relative rarity and the presumption that it is usually mild and not likely to be associated with brain damage (Price \& Weetman 2001, La Franchi 2010, La Franchi 2011). In the Netherlands,

Published by Bioscientifica Ltd 
an unique screening algorithm based on combined measurement of TSH, $\mathrm{T}_{4}$ and thyroxine binding globulin (TBG) results in a diagnosis of $\mathrm{CCH}$ in as many as 1 in 16000 newborns, the majority of whom will have additional pituitary hormone deficits (van Tijn et al. 2005, Kempers et al. 2006). Advantages to case detection by screening include prevention of life-threatening hypoglycaemia due to coexisting GH and/or ACTH deficiency in these individuals as well as enabling early neonatal levothyroxine replacement. A recent study demonstrated that more than $50 \%$ of children with $\mathrm{CCH}$ will have moderate or severe hypothyroidism, such that the potential neurological sequelae of delayed diagnosis should not be underestimated (Persani 2012, ZwavelingSoonawala et al. 2015). However, although the recent ESPE $\mathrm{CH}$ guidelines acknowledge that screening for $\mathrm{CCH}$ fulfils generally accepted disease screening criteria, studies confirming superiority of detection through screening compared with case identification by clinical ascertainment are lacking (Fisher 2005, Leger et al. 2014).

A high index of suspicion is required when investigating for $\mathrm{CCH}$, since early clinical diagnosis is often difficult, and unless the hormone deficit is profound, classical signs of hypothyroidism may be absent. The mainstay of biochemical diagnosis remains the association of low free $\mathrm{T}_{4}$ concentrations with inappropriately low or normal TSH concentrations in the absence of immunoassay interference (Ferretti et al. 1999, Beck-Peccoz 2011, Persani 2012). Circulating $T_{3}$ levels are often normal, due to increased DIO2 activity (Alexopoulou et al. 2004, Sun et al. 2012).

Although biochemical diagnosis of overt central hypothyroidism is generally unequivocal, detection may be more challenging in mild cases where $\mathrm{fT}_{4}$ is only marginally subnormal or when hypothalamic dysfunction results in elevated immunoreative TSH with subnormal bioactivity (Beck-Peccoz 2011). In situations where central thyroid dysfunction evolves with time (eg in children with POU1F1 mutations), declining $\mathrm{fT}_{4}$ concentrations may be an early indicator of $\mathrm{CCH}$, with a time-related decline in $\mathrm{fT}_{4}$ of $>20 \%$ quoted diagnostically in individuals with acquired pituitary disease (Alexopouou et al. 2004). Biochemical markers of thyroid hormone action (eg CPK, cholesterol), lack diagnostic sensitivity but may have a role in monitoring treated cases and may support a diagnosis of CCH (Ferretti et al. 1999). A recent study suggests that $\mathrm{T}_{3}$-dependent echocardiographic parameters may be useful in identifying adults with subclinical central hypothyroidism (Doin et al. 2012). Additional tests that may have a diagnostic role in mild $\mathrm{CCH}$ include evaluation of the nocturnal TSH surge, which is usually absent or blunted even in subclinical cases (Rose et al. 1990, Rose 1995, Roelfsema \& Veldhuis 2013). The TSH index, in which a log-linear relationship between $\mathrm{fT}_{4}$ and TSH is used to predict the normal amount of feedbackinduced change in log TSH per change in $\mathrm{fT}_{4}$, has also been proposed as an estimate of pituitary thyrotroph function, although extrapolation of these results to the paediatric population is challenging (Jostel et al. 2009).

The role of TRH testing in CCH remains controversial, both at diagnosis and in discriminating between pituitary and hypothalamic pathology. Initial studies found a blunted TSH rise to be indicative of pituitary hypothyroidism, whereas an exaggerated, delayed or prolonged TSH response was associated with tertiary hypothyroidism (Costom et al. 1971, Faglia et al. 1973). However, more recent studies in children with central hypothyroidism suggest that TRH testing has both a poor negative predictive value, and an inability to distinguish between hypothalamic and pituitary defects (Mehta et al. 2003). In a study of 54 children with central hypothyroidism, $23.3 \%$ had a normal TRH test, only $30 \%$ had an absent or blunted TSH response suggestive of pituitary disease, whilst 30\% had a delayed hypothalamic response and $16.7 \%$ a brisk response (Mehta et al. 2003). In a different setting, a prospective study of twenty infants diagnosed with central hypothyroidism on neonatal screening, concluded that TRH testing is useful for diagnosis and for distinguishing between patients likely to have isolated or combined pituitary deficiencies, provided that the TSH response to TRH is assayed for at least $180 \mathrm{~min}$ post hormone administration. In this study, the majority of patients with type 2 responses had isolated TSH deficiency (67\%), whilst all patients with type 3 TSH responses to TRH had combined pituitary deficiencies (van Tijn et al. 2008). A prolonged TRH test with a normal TSH increment may enable indirect assessment of TSH bioactivity, quantified by the rise in $\mathrm{fT}_{3}$ and $\mathrm{fT}_{4}$ levels at $120 \mathrm{~min}$ after TRH injection (Yamada \& Mori 2008). However, although this information may help define the mechanism of $\mathrm{CCH}$, further studies are needed to determine normal thyroid hormone responses at these timepoints. In isolated TSH deficiency, additional hormone measurements during TRH testing may enable differentiation between a likely TSHB mutation (preserved prolactin and $\alpha$-subunit responses) and TRHR mutation (blunted responses) (Collu et al. 1997, Bonomi et al. 2001).

In the presence of central hypothyroidism, detailed investigation of the hypothalamo-pituitary axis is indicated as the majority of patients (up to $78 \%$ to $89 \%$ ) will

Published by Bioscientifica Ltd 
have additional pituitary hormone deficiencies (Mehta et al. 2003, Van Tijn et al. 2005). In a series of children with central hypothyroidism, GH deficiency was the most common associated hormone deficiency (89\%), followed by ACTH (78\%) and gonadotropin deficiency (46\%), whilst posterior pituitary dysfunction was evident in a small percentage of patients (13\%), all of who had SOD (Mehta et al. 2003). In this respect, MR imaging is important to detect structural pituitary abnormalities and midline or other CNS defects, and its results may guide genetic testing. Although patients with congenital central hypothyroidism may have a high prevalence of neonatal complications (hypoglycaemia, persisting jaundice, sepsis, seizures, feeding difficulties), the diagnosis of central hypothyroidism was only made in $28 \%$ during the neonatal period (Mehta et al. 2003).

In specific cases, there is a role for targeted genetic screening, depending on the phenotype (Fig. 7). Patients with mutations in transcription factors (eg PROP1, HESX1, SOX3) require long-term surveillance for evolving ACTH and other pituitary hormone deficiencies. Conversely, identification of a genetic defect specific to the TSH biosynthetic pathway (TSHB, TRHR) enables reassurance that additional hormone deficits will not develop. Reports of families with TRHR or IGSF1 mutations also highlight the fact that family screening following diagnosis in a young proband, may identify apparently healthy first, second or third-generation family members with hitherto undiagnosed central hypothyroidism. Untreated subclinical hypothyroidism is associated with adverse cardiometabolic risk, thus these individuals, who have overt central hypothyroidism may benefit from levothyroxine treatment both for cardiovascular health and for quality of life (Razvi et al. 2007, Singh et al. 2008, Bonomi et al. 2009).

\section{Treatment of central hypothyroidism}

Data regarding treatment of central hypothyroidism primarily comes from adults with acquired hypothalamic-pituitary defects and definition of treatment targets remains challenging, since TSH cannot be used as a biomarker of euthyroidism. Furthermore, the negative feedback mechanism in central hypothyroidism may exhibit altered sensitivity to thyroid hormone, such that TSH concentrations above $1.0 \mathrm{mU} / \mathrm{l}$ may reflect insufficient levothyroxine replacement (Carrozza et al. 1999, Ferretti

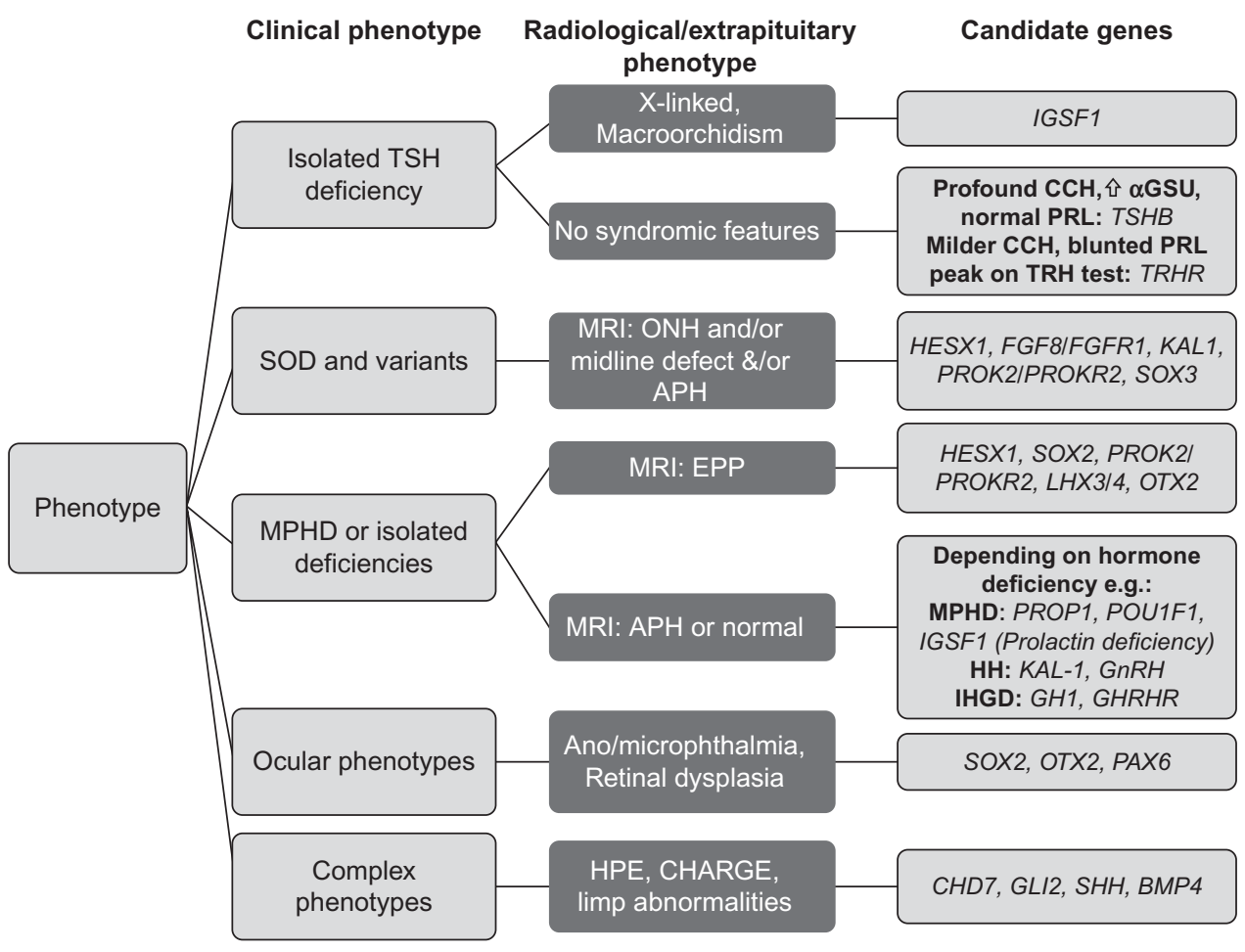

\section{Figure 7}

Proposed strategy for genetic testing in cases with $\mathrm{CCH}$. MPHD, multiple pituitary hormone deficiencies; ONH, optic nerve hypoplasia; HPE, holoprosencephaly; HH, hypogonadotrophic hypogonadism; IHGD, isolated human growth hormone deficiency. http://joe.endocrinology-journals.org DOI: 10.1530/JOE-15-0341 (c) 2015 The authors Printed in Great Britain
Published by Bioscientifica Ltd 
et al. 1999, Shimon et al. 2002). Adequacy of $\mathrm{T}_{4}$ replacement is best assessed by $\mathrm{fT}_{4}$ measurement with the general consensus being that $\mathrm{fT}_{4}$ levels should be maintained in the mid-upper half of the normal range, although a lower target $\mathrm{fT}_{4}$ may be appropriate in the elderly (Ferretti et al. 1999, Slawik et al. 2007, Iverson \& Mariash 2008, Koulouri et al. 2011). $\mathrm{fT}_{3}$ may be more sensitive in detecting overtreatment. Assessment of alternative biomarkers has identified that soluble interleukin 2 receptor (sIL2R) has some utility, but detects overtreatment more readily than undertreatment. SHBG, bone turnover markers, and cholesterol are all sensitive to changes in $\mathrm{fT}_{4}$, but the fact that they are also influenced by GH and gonadal status, renders them unreliable in combined pituitary hormone deficits (Ferretti et al. 1999).

It is imperative that cortisol deficiency is detected and treated before thyroid hormone replacement to avoid a hypoadrenal crisis. Once this is achieved, the drug of choice for treating central hypothyroidism is levothyroxine, with no current evidence to support $T_{3} / T_{4}$ combination therapy (Slawik et al. 2007). The dose needs to be tailored to the age and body weight of the patient, and must accommodate the influence of other hormone deficiencies or drugs. A reasonable target daily replacement dose of $\mathrm{L}-\mathrm{T}_{4}$ would initially be $1.1 \mathrm{mcg} / \mathrm{kg}$ in patients over 60 years of age, 1.3 to $1.6 \mathrm{mcg} / \mathrm{kg}$ for younger adults and 50 to $100 \mu \mathrm{g} / \mathrm{m}^{2}$ per day in children (Ferretti et al. 1999, Slawik et al. 2007, Lania et al. 2008, Koulouri et al. 2011). In children, full replacement should be started immediately and monitored every 2 to 4 weeks initially whereas more cautious dosing may be necessary in the elderly or those with cardiac morbidities. Dose requirements may increase with concomitant oestrogen replacement which increases thyroid hormone binding proteins, and GH replacement, which can also unmask central hypothyroidism (Arafah 2001, Porretti et al. 2002).

\section{Future directions}

The molecular basis for $\mathrm{CCH}$ remains to be ascertained in the majority of cases, raising aetiological questions in this subset. Candidate genes identified from murine models have been helpful in elucidating the basis of combined pituitary hormone deficiencies, and there are additional null mouse models of central hypothyroidism, which implicate other genes as potential candidates for human $\mathrm{CCH}$. Such models include Trh $-/-$ mice which exhibit central hypothyroidism with elevated TSH and hyperglycaemia and glycoprotein $\alpha$ subunit (Cga/Gsu) - /null mice in whom $\mathrm{TSH}, \mathrm{T}_{4}, \mathrm{FSH}$ and $\mathrm{LH}$ are undetectable
(Yamada et al. 1997, Stahl et al. 1999). Additionally, despite the critical role of GATA2 and PITX1 in the development of thyrotropes in murine models, no mutations have as yet been reported in patients with $\mathrm{CCH}$. Perturbed thyroid hormone action and disruption of normal thyroid hormone-mediated negative feedback in the hypothalamus and pituitary may also cause $\mathrm{CCH}$ thus mice expressing a mutant NCOR1 corepressor exhibit central hypothyroidism due to a reset hypothalamicpituitary thyroid axis (Astapova et al. 2011). In affected humans, studies using exome sequencing may also help elucidate less readily predictable causes.

Amongst the known genetic causes of $\mathrm{CCH}$, the function of IGSF1 remains poorly understood and further in vitro and in vivo studies are required to delineate its mechanistic role in the anterior pituitary and its effects on testicular growth. Although current data suggest it is required for adequate TRHR mRNA expression, the expression of IGSF1 in all cells of the POU1F1 lineage and observed abnormalities of other hormone levels (GH, PRL, Testosterone) in deficient humans suggest that its role is more complex. Other cell surface immunoglobulin superfamily members bind specific antigens and interact with other receptors, such that a role for IGSF1 in paracrine signaling in the pituitary is plausible (Joustra et al. 2013a,b, Tajima et al. 2013). Prospective follow up of patients with IGSF1 mutations will help define the natural history of the disease, addressing questions such as whether central hypothyroidism can evolve in carrier females. Additionally, genetic and environmental modifiers of the IGSF1-deficiency phenotype within individual kindreds have yet to be determined.

Long-term outcome studies in congenital central hypothyroidism are required, in particular to formally assess neuropsychological outcomes as a means of assessing adequacy of current diagnostic and treatment algorithms. Identification of robust biochemical or physiological biomarkers of thyroid hormone action will also help in diagnosis or treatment monitoring.

\section{Take home messages}

- $\mathrm{CCH}$ has a higher incidence than previously thought (1:16 000), and delayed diagnosis may result in neurodevelopmental delay.

- $\mathrm{CCH}$ will evade diagnosis on TSH-based screening programmes, therefore a high index of suspicion is needed for prompt detection. The mainstay of biochemical diagnosis is the presence of subnormal T4

Published by Bioscientifica Ltd 
with inappropriately normal/low TSH, after exclusion of assay interference.

- CCH may be isolated or occur as a component of combined pituitary hormone deficiencies (majority of cases). Genetic ascertainment may predict evolution of other hormone deficits and enable prompt diagnosis and treatment of affected siblings.

- In combined pituitary deficits, phenotypes can be highly variable, and can evolve, therefore careful ongoing assessment is required in these patients.

- Family screening in cases with IGSF1 or TRHR mutations is important to identify apparently healthy relatives with hitherto undiagnosed central hypothyroidism who may benefit from levothyroxine treatment.

- Levothyroxine is an effective treatment for $\mathrm{CCH}$; fT4 levels should be maintained in the mid-upper part of the normal range.

- Cortisol deficiency should be corrected before initiation of levothyroxine and the clinician should be alert to the fact that other hormone replacements (GH, oestrogen) may alter levothyroxine requirements.

\section{Declaration of interest}

The authors declare that there is no conflict of interest that could be perceived as prejudicing the impartiality of this review.

\section{Funding}

This work was supported by funding from the Wellcome Trust (Grant $100585 / Z / 12 / Z$ to N S, Grant $095564 / Z / 11 / Z$ to $K$ C).

\section{Acknowledgements}

The authors acknowledge $\mathrm{Dr}$ Erik Schoenmakers for performing the structural modeling of TSHB and TRHR.

\section{References}

Acampora D, Mazan S, Lallemand Y, Avantaggiato V, Maury M, Simeone A \& Brûlet P 1995 Forebrain and midbrain regions are deleted in Otx2-1- mutants due to a defective anterior neuroectoderm specification during gastrulation. Development 121 3279-3290.

Alatzoglou KS \& Dattani MT 2009 Genetic forms of hypopituitarism and their manifestation in the neonatal period. Early Human Development 85 705-712. (doi:10.1016/j.earlhumdev.2009.08.057)

Alatzoglou KS, Azriyanti A, Rogers N, Ryan F, Curry N, Noakes C, Bignell P, Hall GW, Littooij AS, aunders D et al. 2014 SOX3 deletion in mouse and human is associated with persistence of the craniopharyngeal canal. Journal of Clinical Endocrinology and Metabolism 99 E2702-E2708. (doi:10.1210/jc.2014-1160)

Alexopoulou O, Beguin C, De Nayer P \& Maiter D 2004 Clinical and hormonal characteristics of central hypothyroidism at diagnosis and during follow-up in adult patients. European Journal of Endocrinology $\mathbf{1 5 0}$ 1-8. (doi:10.1530/eje.0.1500001)

Alkemade A 2015 Thyroid hormone and the developing hypothalamus. Frontiers in Neuroanatomy 9 15. (doi:10.3389/fnana.2015.00015)

Alkemade A, Friesema EC, Kalsbeek A, Swaab DF, Visser TJ \& Fliers E 2011 Expression of thyroid hormone transporters in the human hypothalamus. Journal of Clinical Endocrinology and Metabolism 6 E967-E971. (doi:10.1210/jc.2010-2750)

Arafah BM 2001 Increased need for thyroxine in women with hypothyroidism during estrogen therapy. New England Journal of Medicine $\mathbf{3 4 4}$ 1743-1749. (doi:10.1056/NEJM200106073442302)

Astapova I, Vella KR, Ramadoss P, Holtz KA, Rodwin BA, Liao XH, Weiss RE, Rosenberg MA, Rosenzweig A \& Hollenberg AN 2011 The nuclear receptor corepressor (NCoR) controls thyroid hormone sensitivity and the set point of the hypothalamic-pituitary-thyroid axis. Molecular Endocrinology 25 212-224. (doi:10.1210/me.2010-0462)

Baquedano MS, Ciaccio M, Dujovne N, Herzovich V, Longueira Y, Warman DM, Rivarola MA \& Belgorosky A 2010 Two novel mutations of the TSH- $\beta$ subunit gene underlying congenital central hypothyroidism undetectable in neonatal TSH screening. Journal of Clinical Endocrinology and Metabolism 95 E98-103. (doi:10.1210/jc.2010-0223)

Beck-Peccoz P 2011 Treatment of central hypothyroidism. Clinical Endocrinology 74 671-672. (doi:10.1111/j.1365-2265.2011.04037.x)

Bernard DJ, Burns KH, Haupt B, Matzuk MM \& Woodruff TK 2003 Normal reproductive function in InhBP/p120-deficient mice. Molecular and Cellular Biology 23 4882-4891. (doi:10.1128/MCB.23.14.4882-4891. 2003)

Bilodeau S, Roussel-Gervais A \& Drouin J 2009 Distinct developmental roles of cell cycle inhibitors p57Kip2 and p27Kip1 distinguish pituitary progenitor cell cycle exit from cell cycle reentry of differentiated cells. Molecular and Cellular Biology 29 1895-1908. (doi:10.1128/MCB. 01885-08)

Boncinelli E \& Morgan R 2001 Downstream of Otx2, or how to get a head. Trends in Analytical Chemistry 17 633-636.

Bonomi M, Proverbio MC, Weber G, Chiumello G, Beck-Peccoz P \& Persani L 2001 Hyperplastic pituitary gland, high serum glycoprotein hormone $\alpha$-subunit, and variable circulating thyrotropin (TSH) levels as hallmark of central hypothyroidism due to mutations of the TSH $\beta$ gene. Journal of Clinical Endocrinology and Metabolism 86 1600-1604.

Bonomi M, Busnelli M, Beck-Peccoz P, Costanzo D, Antonica F, Dolci C, Pilotta A, Buzi F \& Persani L 2009 A family with complete resistance to thyrotropin-releasing hormone. New England Journal of Medicine 360 731-734. (doi:10.1056/NEJMc0808557)

Brumm H, Pfeufer A, Biebermann H, Schnabel D, Deiss D \& Gruters A 2002 Congenital central hypothyroidism due to homozygous thyrotropin $\beta$ $313 \delta$ T mutation is caused by a founder effect. Journal of Clinical Endocrinology and Metabolism 87 4811-4816. (doi:10.1210/jc.2002020297)

Camper SA, Saunders TL, Katz RW \& Reeves RH 1990 The Pit-1 transcription factor gene is a candidate for the murine Snell dwarf mutation. Genomics 8 586-590. (doi:10.1016/0888-7543(90)90050-5)

Carrozza V, Csako G, Yanovski JA, Skarulis MC, Nieman L, Wesley R \& Pucino F 1999 Levothyroxine replacement therapy in central hypothyroidism: a practice report. Pharmacotherapy 19 349-355. (doi:10.1592/phco.19.4.349.30940)

Carvalho LR, Woods KS, Mendonca BB, Marcal N, Zamparini AL, Stifani S, Brickman JM, Arnhold IJ \& Dattani MT 2003 A homozygous mutation in HESX1 is associated with evolving hypopituitarism due to impaired repressor-corepressor interaction. Journal of Clinical Investigation 112 1192-1201. (doi:10.1172/JCI18589)

Castinetti F, Saveanu A, Reynaud R, Quentien MH, Buffin A, Brauner R, Kaffel N, Albarel F, Guedj AM, El Kholy M et al. 2008 A novel dysfunctional LHX4 mutation with high phenotypical variability in patients with hypopituitarism. Journal of Clinical Endocrinology and Metabolism 93 2790-2799. (doi:10.1210/jc.2007-2389) http://joe.endocrinology-journals.org DOI: 10.1530/JOE-15-0341 (c) 2015 The authors Printed in Great Britain
Published by Bioscientifica Ltd 
Castinetti F, Brinkmeier ML, Gordon DF, Vella KR, Kerr JM, Mortensen AH, Hollenberg A, Brue T, Ridgway EC \& Camper SA 2011 PITX2 AND PITX1 regulate thyrotroph function and response to hypothyroidism. Molecular Endocrinology 25 1950-1960. (doi:10.1210/me.2010-0388)

Chapman SC \& Woodruff TK 2001 Modulation of activin signal transduction by inhibin B and inhibin-binding protein (INhBP). Molecular Endocrinology 15 668-679. (doi:10.1210/mend.15.4.0616)

Chapman SC, Bernard DJ, Jelen J \& Woodruff TK 2002 Properties of Inhibin binding to $\beta$ glycan. InhBP/p120 and the activin type II receptors. Molecular and Cellular Endocrinology 196 79-93. (doi:10.1016/S03037207(02)00227-7)

Charles MA, Saunders TL, Wood WM, Owens K, Parlow AF, Camper SA, Ridgway EC \& Gordon DF 2006 Pituitary-specific Gata2 knockout: effects on gonadotrope and thyrotrope function. Molecular Endocrinology 20 1366-1377. (doi:10.1210/me.2005-0378)

Cheng S-Y, Leoonard JL \& Davis PJ 2010 Molecular aspects of thyroid hormone actions. Endocrine Reviews 31 139-170. (doi:10.1210/er.20090007)

Chong H, Pangas SA, Bernard DJ, Wang E, Gitch J, Chen W, Draper LB, Cox ET \& Woodruff TK 2000 Structure and expression of a membrane component of the inhibin receptor system. Endocrinology 141 2600-2607.

Collu R, Tang J, Castagné J, Lagacé G, Masson N, Huot C, Deal C, Delvin E, Faccenda E, Eidne KA et al. 1997 A novel mechanism for isolated central hypothyroidism: inactivating mutations in the thyrotropin-releasing hormone receptor gene. Journal of Clinical Endocrinology and Metabolism 82 1561-1565.

Costom BH, Grumbach MM \& Kaplan SL 1971 effect of thyrotropinreleasing factor on serum thyroid-stimulating hormone. An approach to distinguishing hypothalamic from pituitary forms of idiopathic hypopituitary dwarfism. Journal of Clinical Investigation 50 2219-2225. (doi:10.1172/JCI106717)

Cushman LJ, Watkins-Chow DE, Brinkmeier ML, Raetzman LT, Radak AL, Lloyd RV \& Camper SA 2001 Persistent Prop1 expression delays gonadotrope differentiation and enhances pituitary tumor susceptibility. Human Molecular Genetics 10 1141-1153. (doi:10.1093/hmg/10. 11.1141)

Dacou-Voutetakis C, Feltquate DM, Drakopoulou M, Kourides IA \& Dracopoli NC 1990 Familial hypothyroidism caused by a nonsense mutation in the thyroid-stimulating hormone $\beta$-subunit gene. American Journal of Human Genetics 46 988-993.

Dasen JS, O'Connell SM, Flynn SE, Treier M, Gleiberman AS, Szeto DP, Hooshmand F, Aggarwal AK \& Rosenfeld MG 1999 Reciprocal interactions of Pit1 and GATA2 mediate signaling gradient-induced determination of pituitary cell types. Cell 97 587-598. (doi:10.1016/ S0092-8674(00)80770-9)

Dateki S, Fukami M, Sato N, Muroya K, Adachi M \& Ogata T 2008 OTX2 mutation in a patient with anophthalmia, short stature, and partial growth hormone deficiency: functional studies using the IRBP, HESX1, and POU1F1 promoters. Journal of Clinical Endocrinology and Metabolism 93 3697-3702. (doi:10.1210/jc.2008-0720)

Dattani MT, Martinez-Barbera JP, Thomas PQ, Brickman JM, Gupta R, Mårtensson IL, Toresson H, Fox M, Wales JK, Hindmarsh PC et al. 1998 Mutations in the homeobox gene HESX1/Hesx1 associated with septooptic dysplasia in human and mouse. Nature Genetics 19 125-133. (doi:10.1038/477)

Dattani MT, Martinez-Barbera JP, Thomas PQ, Brickman JM, Gupta R, Wales JK, Hindmarsh PC, Beddington RS \& Robinson IC 1999 HESX1: a novel gene implicated in a familial form of septo-optic dysplasia. Acta Paediatric Supplementum 88 49-54. (doi:10.1111/j.1651-2227.1999. tb14403.x)

Davis SW, Mortensen AH \& Camper SA 2011 Birthdating studies reshape models for pituitary gland cell specification. Developmental Biology 352 215-227. (doi:10.1016/j.ydbio.2011.01.010)

Deladoëy J, Vuissoz JM, Domené HM, Malik N, Gruneiro-Papendieck L, Chiesa A, Heinrich JJ \& Mullis PE 2003 Congenital secondary hypothyroidism due to a mutation C105Vfs114X thyrotropin- $\beta$ mutation: genetic study of five unrelated families from Switzerland and Argentina. Thyroid 13 553-559.

Diaczok D, Romero C, Zunich J, Marshall I \& Radovick S 2008 A novel dominant negative mutation of OTX2 associated with combined pituitary hormone deficiency. Journal of Clinical Endocrinology and Metabolism 93 4351-4359. (doi:10.1210/jc.2008-1189)

Díaz C, Morales-Delgado N \& Puelles L 2015 Ontogenesis of peptidergic neurons within the genoarchitectonic map of the mouse hypothalamus. Frontiers in Neuroanatomy 8 162. (doi:10.3389/fnana. 2014.00162)

Doin FC, Rosa-Borges M, Martins MR, Moisés VA \& Abucham J 2012 Diagnosis of subclinical central hypothyroidism in patients with hypothalamic-pituitary disease by Doppler echocardiography. European Journal of Endocrinology 166 631-640. (doi:10.1530/EJE-11-0907)

Domene HM, Gruneiro-Papendieck L, Chiesa A, Iorcansky S, Herzovich V, Papazian R, Forclaz V, Prieto L, Sanso G, caglia P et al. 2004 The C105fs114X Is the prevalent thyrotropin $\beta$-subunit gene mutation in argentinean patients with congenital central hypothyroidism. Hormone Research in Paediatrics 61 41-46. (doi:10.1159/000075196)

Drees JC, Stone JA, Reamer CR, Arboleda VE, Huang K, Hrynkow J, Greene DN, Petrie MS, Hoke C, Lorey TS et al. 2014 Falsely undetectable TSH in a cohort of South Asian euthyroid patients. Journal of Clinical Endocrinology and Metabolism 99 1171-1179. (doi:10.1210/ jc.2013-2092)

Drouin J, Bilodeau S \& Roussel-Gervais A 2010 Stem cells, differentiation and cell cycle control in pituitary. Frontiers of Hormone Research $\mathbf{3 8}$ $15-24$.

Ericson J, Norlin S, Jessell TM \& Edlund T 1998 Integrated FGF and BMP signaling controls the progression of progenitor cell differentiation and the emergence of pattern in the embryonic anterior pituitary. Development 125 1005-1015.

Estrada JM, Soldin D, Buckey TM, Burman KD \& Soldin OP 2014 Thyrotropin isoforms: implications for thyrotropin analysis and clinical practice. Thyroid 24 411-423. (doi:10.1089/thy.2013.0119)

Faglia G, Beck-Peccoz P, Ferrari C, Ambrosi B, Spada A, Travaglini P \& Paracchi S 1973 Plasma thyrotropin response to thyrotropin-releasing hormone in patients with pituitary and hypothalamic disorders. Journal of Clinical Endocrinology and Metabolism 37 595-601. (doi:10.1210/jcem-37-4-595)

Faucz FR, Horvath AD, Azevedo MF, Levy I, Bak B, Wang Y, Xekouki P, Szarek E, Gourgari E, Manning AD et al. 2015 Is IGSF1 involved in human pituitary tumor formation? Endocrine-Related Cancer 22 47-54. (doi:10.1530/ERC-14-0465)

Fekete C \& Lechan RM 2014 Central regulation of the hypothalamicpituitary-thyroid axis under physiological and pathophysiological conditions. Endocrine Reviews 35 159-194. (doi:10.1210/er.2013-1087)

Ferretti E, Persani L, Jaffrain-Rea ML, Giambona S, Tamburrano G \& BeckPeccoz P 1999 Evaluation of the adequacy of $\mathrm{L}-\mathrm{T}_{4}$ replacement therapy in patients with central hypothyroidism. Journal of Clinical Endocrinology and Metabolism 84 924-929.

Fisher D 2005 Next generation newborn screening for congenital hypothyroidism? Journal of Clinical Endocrinology and Metabolism 90 3797-3799. (doi:10.1210/jc.2005-0851)

Fliers E, Unmehopa U \& Alkemade A 2006 Functional neuroanatomy of thyroid hormone feedback in the human hypothalamus and pituitary gland. Molecular and Cellular Endocrinology 251 1-8. (doi:10.1016/j.mce. 2006.03.042)

Fluck C, Deladoey J, Rutishauser K, Eble A, Marti U, Wu W \& Mullis PE 1998 Phenotypic variability in familial combined pituitary hormone deficiency caused by a PROP1 gene mutation resulting in the substitution of Arg-> Cys at codon 120 (R120C). Journal of Clinical Endocrinology and Metabolism 83 3727-3734.

García M, Fernández A, Moreno JC 2014 Central hypothyroidism in children. In Paediatric Thyroidology. Endocrine Development 26 pp 79-107. Ed G Szinnai Basel, Karger. 
Gordon DF, Woodmansee WW, Black JN, Dowding JM, Bendrick-Peart J, Wood WM \& Ridgway EC 2002 Domains of Pit-1 required for transcriptional synergy with GATA-2 on the TSH $\beta$ gene. Molecular and Cellular Endocrinology 196 53-66. (doi:10.1016/S0303-7207(02) 00223-X)

Hayashizaki Y, Hiraoka Y, Endo Y, Miyai K \& Matsubara K 1989 Thyroid-stimulating hormone (TSH) deficiency caused by a single base substitution in the CAGYC region of the $\beta$-subunit. EMBO Journal 8 2291-2296.

Hermanns P, Couch R, Leonard N, Klotz C \& Pohlenz J 2014 A novel deletion in the thyrotropin $\beta$-subunit gene identified by array comparative genomic hybridization analysis causes central congenital hypothyroidism in a boy originating from Turkey. Hormone Research in Paediatrics 82 201-205. (doi:10.1159/000362413)

Himes AD \& Raetzman LT 2009 Premature differentiation and aberrant movement of pituitary cells lacking both Hes1 and Prop1. Developmental Biology 325 151-161. (doi:10.1016/j.ydbio.2008.10.010)

Hinkle PM, Gehret AU \& Jones BW 2012 Desensitization, trafficking and resensitization of the pituitary thyrotropin-releasing hormone receptor. Frontiers in Neuroscience 6 180. (doi:10.3389/fnins.2012.00180)

Hollenberg AN, Monden T, Flynn TR, Boers ME, Cohen O \& Wondisford FE 1995 The human thyrotropin-releasing hormone gene is regulated by thyroid hormone through two distinct classes of negative thyroid hormone response elements. Molecular Endocrinology 9 540-550.

Holsberger DR \& Cooke PS 2005 Understanding the role of thyroid hormone in Sertoli cell development: a mechanistic hypothesis. Cell and Tissue Research 322 133-140. (doi:10.1007/s00441-005-1082-z)

Horjales-Araujo E, Hellysaz A \& Broberger C 2014 Lateral hypothalamic thyrotropin-releasing hormone neurons: distribution and relationship to histochemically defined cell populations in the rat. Neuroscience $\mathbf{2 7 7}$ 87-102. (doi:10.1016/j.neuroscience.2014.06.043)

Iverson JF \& Mariash CN 2008 Optimal free thyroxine levels for thyroid hormone replacement in hypothyroidism. Endocrine Practice 14550 555. (doi:10.4158/EP.14.5.550)

Jiang X, Dias JA \& He X 2014 Structural biology of glycoprotein hormones and their receptors: insights to signaling. Molecular and Cellular Endocrinology 382 424-451. (doi:10.1016/j.mce.2013. 08.021)

Jostel A, Ryder WD \& Shalet SM 2009 The use of thyroid function tests in the diagnosis of hypopituitarism: definition and evaluation of the TSH Index. Clinical Endocrinology 71 529-534. (doi:10.1111/j.1365-2265. 2009.03534.x)

Joustra SD, van Trotsenburg AS, Sun Y, Losekoot M, Bernard DJ, Biermasz NR, Oostdijk W \& Wit JM 2013a IGSF1 deficiency syndrome: a newly uncovered endocrinopathy. Orphanet Journal of Rare Diseases $\mathbf{1}$ e24883. (doi:10.4161/rdis.24883)

Joustra SD, Schoenmakers N, Persani L, Campi I, Bonomi M, Radetti G, Beck-Peccoz P, Zhu H, Davis TM, un Y et al. 2013b The IGSF1 deficiency syndrome: characteristics of male and female patients. Journal of Clinical Endocrinology and Metabolism 98 4942-4952. (doi:10.1210/jc. 2013-2743)

Joustra SD, Meijer OC, Heinen C, Mol I, Laghmani EH, Sengers R, Carreno G, vanTrotsenburg P, Biermasz NR \& Bernard DJ 2015a Spatial and temporal expression of immunoglobulin superfamily member 1 (IGSF1) in the rat. Journal of Endocrinology 226 181-191. (doi:10.1530/ JOE-15-0204)

Joustra SD, Wehkalampi K, Oostdijk W, Biermasz NR, Howard S, Silander TL, Bernard DJ, Wit JM, Dunkel L \& Losekoot M 2015b IGSF1 variants in boys with familial delayed puberty. European Journal of Pediatrics 174 687-692. (doi:10.1007/s00431-014-2445-9)

Karges B, LeHeup B, Schoenle E, Castro-Correia C, Fontoura M, Pfäffle R, Andler W, Debatin KM \& Karges W 2004 Compound heterozygous and homozygous mutations of the TSH $\beta$ gene as a cause of congenital central hypothyroidism in Europe. Hormone Research 62 149-155. (doi:10.1159/000080071)
Kelberman D, Rizzoti K, Lovell-Badge R, Robinson IC \& Dattani MT 2009 Genetic regulation of pituitary gland development in human and mouse. Endocrine Reviews 30 790-829. (doi:10.1210/er.2009-0008)

Kempers MJ, Lanting CI, van Heijst AF, van Trotsenburg AS, Wiedijk BM, de Vijlder JJ \& Vulsma T 2006 Neonatal screening for congenital hypothyroidism based on thyroxine, thyrotropin, and thyroxine-binding globulin measurement: potentials and pitfalls. Journal of Clinical Endocrinology and Metabolism 91 3370-3376. (doi:10.1210/jc.2006-0058)

Koulouri O, Auldin MA, Agarwal R, Kieffer V, Robertson C, FalconerSmith J, Levy MJ \& Howlett TA 2011 Diagnosis and treatment of hypothyroidism in TSH deficiency compared to primary thyroid disease: pituitary patients are at risk of under-replacement with levothyroxine. Clinical Endocrinology 74 744-749. (doi:10.1111/j.1365-2265.2011.03984.x)

Kugler JA \& Huseman CA 1983 Primary hypothyroidism of childhood: evaluation of the hypothalamic-pituitary gonadal axis before and during L-thyroxine replacement. Clinical Endocrinology 19 213-222. (doi:10.1111/j.1365-2265.1983.tb02983.x)

Kurokawa D, Kiyonari H, Nakayama R, Kimura-Yoshida C, Matsuo I \& Aizawa S 2004 Regulation of Otx2 expression and its functions in mouse forebrain and midbrain. Development 131 3319-3331. (doi:10.1242/dev.01220)

La Franchi SH 2010 Newborn screening strategies for congenital hypothyroidism: an update. Journal of Inherited Metabolic Disease 33(Suppl 2) S225-S233. (doi:10.1007/s10545-010-9062-1)

La Franchi SH 2011 Approach to the diagnosis and treatment of neonatal hypothyroidism. Journal of Clinical Endocrinology and Metabolism 96 2959-2967. (doi:10.1210/jc.2011-1175)

Lanctôt C, Gauthier Y \& Drouin J 1999 Pituitary homeobox 1 (Ptx1) is differentially expressed during pituitary development. Endocrinology 140 1416-1422.

Lania A, Persani L \& Beck-Peccoz P 2008 Central hypothyroidism. Pituitary 11 181-186. (doi:10.1007/s11102-008-0122-6)

Laumonnier F, Ronce N, Hamel BC, Thomas P, Lespinasse J, Raynaud M, Paringaux C, Van Bokhoven H, Kalsheuer V, Fryns JP et al. 2002 Transcription factor SOX3 is involved in X-linked mental retardation with growth hormone deficiency. American Journal of Human Genetics 71 1450-1455. (doi:10.1086/344661)

Léger J, Olivieri A, Donaldson M, Torresani T, Krude H, van Vliet G, Polak M \& Butler G 2014 ESPE-PES-SLEP-JSPE-APEG-APPES-ISPAE; Congenital Hypothyroidism Consensus Conference Group, European Society for Paediatric Endocrinology consensus guidelines on screening, diagnosis, and management of congenital hypothyroidism. Journal of Clinical Endocrinology and Metabolism 99 363-368.

Matsushita A, Sasaki S, Kashiwabara Y, Nagayama K, Ohba K, Iwaki H, Misawa H, Ishizuka K \& Nakamura H 2007 Essential role of GATA2 in the negative regulation of thyrotropin $\beta$ gene by thyroid hormone and its receptors. Molecular Endocrinology 21 865-884. (doi:10.1210/me. 2006-0208)

McCabe MJ, Gaston-Massuet C, Tziaferi V, Gregory LC, Alatzoglou KS, Signore M, Puelles E, Gerrelli D, Farooqi IS, aza J et al. 2011 Novel FGF8 mutations associated with recessive holoprosencephaly, craniofacial defects, and hypothalamo-pituitary dysfunction. Journal of Clinical Endocrinology and Metabolism 96 E1709-E1718. (doi:10.1210/jc.20110454)

McCabe MJ, Gaston-Massuet C, Gregory LC, Alatzoglou KS, Tziaferi V, Sbai O, Rondard P, Masumoto KH, Nagano M, higeyoshi Y et al. 2013 Variations in PROKR2, but not PROK2, are associated with hypopituitarism and septo-optic dysplasia. Journal of Clinical Endocrinology and Metabolism 98 E547-E557. (doi:10.1210/jc.2012-3067)

McDermott MT, Haugen BR, Black JN, Wood WM, Gordon DF \& Ridgway EC 2002 Congenital isolated central hypothyroidism caused by a 'hot spot' mutation in the thyrotropin- $\beta$ gene. Thyroid 12 1141-1146. (doi:10.1089/105072502321085252)

McNay DE, Turton JP, Kelberman D, Woods KS, Brauner R, Papadimitriou A, Keller E, Keller A, Haufs N, rude $\mathrm{H}$ et al. 2007 HESX1 mutations are

Published by Bioscientifica Ltd 
an uncommon cause of septooptic dysplasia and hypopituitarism. Journal of Clinical Endocrinology and Metabolism 92 691-697. (doi:10.1210/jc.2006-1609)

Medeiros-Neto G, Herodotou DT, Rajan S, Kommareddis S, de Lacerdal L, Sandrini R, Boguszewski MC, Hollenberg AN, Radovick S \& Wondisford FE 1996 A circulating, biologically inactive thyrotropin caused by a mutation in the $\beta$ subunit gene. Journal of Clinical Investigation 97 1250-1256. (doi:10.1172/JCI118540)

Mehta A, Hindmarsh PC, Stanhope RG, Brain CE, Preece MA \& Dattani MT 2003 Is the thyrotropin-releasing hormone test necessary in the diagnosis of central hypothyroidism in children. Journal of Clinical Endocrinology and Metabolism 88 5696-5703. (doi:10.1210/jc.2003030943)

Morales AE, Shi JD, Wang CY, She JX \& Muir A 2004 Novel TSH $\beta$ subunit gene mutation causing congenital central hypothyroidism in a newborn male. Journal of Pediatric Endocrinology and Metabolism 17 355-359. (doi:10.1515/JPEM.2004.17.3.355)

Mullen RD, Colvin SC, Hunter CS, Savage JJ, Walvoord EC, Bhangoo AP, Ten S, Weigel J, Pfäffle RW \& Rhodes SJ 2007 Roles of the LHX3 and LHX4 LIM-homeodomain factors in pituitary development. Molecular and Cellular Endocrinology 265-266 190-195.

Nakamura A, Bak B, Silander TL, Lam J, Hotsubo T, Yorifuji T, Ishizu K, Bernard DJ \& Tajima T 2013 Three novel IGSF1 mutations in four Japanese patients with X-linked congenital central hypothyroidism. Journal of Clinical Endocrinology and Metabolism 98 E1682-E1691. (doi:10.1210/jc.2013-1224)

Nasonkin IO, Ward RD, Raetzman LT, Seasholtz AF, Saunders TL, Gillespie PJ \& Camper SA 2004 Pituitary hypoplasia and respiratory distress syndrome in Prop1 knockout mice. Human Molecular Genetics 13 2727-2735. (doi:10.1093/hmg/ddh311)

Netchine I, Sobrier ML, Krude H, Schnabel D, Maghnie M, Marcos E, Duriez B, Cacheux V, Moers AV, Goossens M et al. 2000 Mutations in LHX3 result in a new syndrome revealed by combined pituitary hormone deficiency. Nature Genetics 25 182-186. (doi:10.1038/76041)

Olson LE, Tollkuhn J, Scafoglio C, Krones A, Zhang J, Ohgi KA, Wu W, Taketo MM, Kemler R, rosschedl R et al. 2006 Homeodomain-mediated $\beta$-catenin-dependent switching events dictate cell-lineage determination. Cell 125 593-605. (doi:10.1016/j.cell.2006.02.046)

Ortiga-Carvalho TM, Sidhaye AR \& Wondisford FE 2014 Thyroid hormone receptors and resistance to thyroid hormone disorders. Nature Reviews. Endocrinology 10 582-591. (doi:10.1038/nrendo.2014.143)

Pappa T, Johannesen J, Scherberg N, Torrent M, Dumitrescu A \& Refetoff S 2015 A TSHB variant with impaired immunoreactivity but intact biological activity and its clinical implications. Thyroid 25 869-876. (doi:10.1089/thy.2015.0096)

Perello M, Friedman T, Paez-Espinosa V, Shen X, Stuart RC \& Nillni E 2006 Thyroid hormones selectively regulate the posttranslational processing of prothyrotropin-releasing hormone in the paraventricular nucleus of the hypothalamus. Endocrinology 147 2705-2716. (doi:10.1210/en. 2005-1609)

Persani L 1988 Hypothalamic thyrotropin-releasing hormone and thyrotropin biological activity. Thyroid 10 941-946

Persani L 2012 Clinical review: central hypothyroidism: pathogenic, diagnostic, and therapeutic challenges. Journal of Clinical Endocrinology and Metabolism 97 3068-3078. (doi:10.1210/jc.2012-1616)

Pfaeffle RW, Hunter CS, Savage JJ, Duran-Prado M, Mullen RD, Neeb ZP, Eiholzer U, Hesse V, Haddad NG, Stobbe HM et al. 2008 Three novel missense mutations within the LHX4 gene are associated with variable pituitary hormone deficiencies. Journal of Clinical Endocrinology and Metabolism 93 1062-1071. (doi:10.1210/jc.2007-1525)

Pohlenz J, Dumitrescu A, Aumann U, Koch G, Melchior R, Prawitt D \& Refetoff S 2002 Congenital secondary hypothyroidism caused by exon skipping due to a homozygous donor splice site mutation in the TSH $\beta$-subunit gene. Journal of Clinical Endocrinology and Metabolism $\mathbf{8 7}$ 336-339.
Porretti S, Giavoli C, Ronchi C, Lombardi G, Zaccaria M, Valle D, Arosio M \& Beck-Peccoz P 2002 Recombinant human GH replacement therapy and thyroid function in a large group of adult GH-deficient patients: when does L-T(4) therapy become mandatory? Journal of Clinical Endocrinology and Metabolism 87 2042-2045. (doi:10.1210/jcem.87. 5.8479)

Price A \& Weetman AP 2001 Screening for central hypothyroidism is unjustified. BMJ 322 798. (doi:10.1136/bmj.322.7289.798)

Prummel MF, Brokken LJ \& Wiersinga WM 2004 Ultra short-loop feedback control of thyrotropin secretion. Thyroid 14 825-829. (doi:10.1089/thy. 2004.14.825)

Rabeler R, Mittag J, Geffers L, Rüther U, Leitges M, Parlow AF, Visser TJ \& Bauer K 2004 Generation of thyrotropin-releasing hormone receptor 1-deficient mice as an animal model of central hypothyroidism. Molecular Endocrinology 18 1450-1460. (doi:10.1210/me.2004-0017)

Rajab A, Kelberman D, deCastro SC, Biebermann H, Shaikh H, Pearce K, Hall CM, Shaikh G, Gerrelli D, rueters A et al. 2008 Novel mutations in LHX3 are associated with hypopituitarism and sensorineural hearing loss. Human Molecular Genetics 17 2150-2159. (doi:10.1093/hmg/ ddn114)

Razvi S, Ingoe L, Keeka G, Oates C, McMillan C \& Weaver JU 2007 The beneficial effect of L-thyroxine on cardiovascular risk factors, endothelial function, and quality of life in subclinical hypothyroidism: randomized, crossover trial. Journal of Clinical Endocrinology and Metabolism 92 1715-1723. (doi:10.1210/jc.2006-1869)

Rizzoti K \& Lovell-Badge R 2005 Early development of the pituitary gland: induction and shaping of Rathke's pouch. Reviews in Endocrine and Metabolic Disorders 6 161-172. (doi:10.1007/s11154-005-3047-7)

Rizzoti K, Brunelli S, Carmignac D, Thomas PQ, Robinson IC \& LovellBadge R 2004 SOX3 is required during the formation of the hypothalamo-pituitary axis. Nature Genetics 36 247-255. (doi:10.1038/ ng1309)

Robakis T, Bak B, Lin SH, Bernard DJ \& Scheiffele P 2008 An internal signal sequence directs intramembrane proteolysis of a cellular immunoglobulin domain protein. Journal of Biological Chemistry 283 36369-36376. (doi:10.1074/jbc.M807527200)

Roelfsema F \& Veldhuis JD 2013 Thyrotropin secretion patterns in health and disease. Endocrine Reviews 34 619-657. (doi:10.1210/er.2012-1076)

Rose SR 1995 Isolated central hypothyroidism in short stature. Pediatric Research 38 967-973. (doi:10.1203/00006450-199512000-00023)

Rose SR, Manasco PK, Pearce S \& Nisula BC 1990 Hypothyroidism and deficiency of the nocturnal thyrotropin surge in children with hypothalamic-pituitary disorders. Journal of Clinical Endocrinology and Metabolism 70 1750-1755. (doi:10.1210/jcem-70-6-1750)

Ryan GL, Feng X, d'Alva CB, Zhang M, Van Voorhis BJ, Pinto EM, Kubias AE, Antonini SR, Latronico AC \& Segaloff DL 2007 Evaluating the roles of follicle-stimulating hormone receptor polymorphisms in gonadal hyperstimulation associated with severe juvenile primary hypothyroidism. Journal of Clinical Endocrinology and Metabolism 92 2312-2317. (doi:10.1210/jc.2006-2086)

Sajedi E, Gaston-Massuet C, Signore M, Andoniadou CL, Kelberman D, Castro S, Etchevers HC, Gerrelli D, Dattani MT \& Martinez-Barbera JP 2008 Analysis of mouse models carrying the I26T and R160C substitutions in the transcriptional repressor HESX1 as models for septo-optic dysplasia and hypopituitarism. Disease Models \& Mechanisms 1 241-254. (doi:10.1242/dmm.000711)

Santos GM, Fairall L \& Schwabe J 2011 Negative regulation by nuclear receptors: a plethora of mechanisms. Trends in Endocrinology and Metabolism 22 87-93. (doi:10.1016/j.tem.2010.11.004)

Sertedaki A, Papadimitriou A, Voutetakis A, Dracopoulou M, Maniati-Christidi M \& Dacou-Voutetakis C 2002 Low TSH congenital hypothyroidism: identification of a novel mutation of the TSH $\beta$-subunit gene in one sporadic case (C85R) and of mutation Q49stop in two siblings with congenital hypothyroidism. Pediatric Research 52 935-941.

Published by Bioscientifica Ltd 
Sheng HZ \& Westphal H 1999 Early steps in pituitary organogenesis. Trends in Analytical Chemistry 15 236-240.

Sheng HZ, Zhadanov AB, Mosinger B Jr, Fujii T, Bertuzzi S, Grinberg A, Lee EJ, Huang SP, Mahon KA \& Westphal H 1996 Specification of pituitary cell lineages by the LIM homeobox gene Lhx3. Science $\mathbf{2 7 2}$ 1004-1007. (doi:10.1126/science.272.5264.1004)

Sheng HZ, Moriyama K, Yamashita T, Li H, Potter SS, Mahon KA \& Westphal H 1997 Multistep control of pituitary organogenesis. Science 278 1809-1812. (doi:10.1126/science.278.5344.1809)

Shimogori T, Lee DA \& Miranda-Angulo A 2010 A genomic atlas of mouse hypothalamic development. Nature Neuroscience 13 767-775. (doi:10.1038/nn.2545)

Shimon I, Cohen O, Lubetsky A \& Olchovsky D 2002 Thyrotropin suppression by thyroid hormone replacement is correlated with thyroxine level normalization in central hypothyroidism. Thyroid $\mathbf{1 2}$ 823-827. (doi:10.1089/105072502760339406)

Shupnik MA, Chin WW, Habener JF \& Ridgway EC 1985 Transcriptional regulation of the thyrotropin subunit genes by thyroid hormone. Journal of Biological Chemistry 260 2900-2903.

Singh S, Duggal J, Molnar J, Maldonado F, Barsano CP \& Arora R 2008 Impact of subclinical thyroid disorders on coronary heart disease, cardiovascular and all-cause mortality: a meta-analysis. International Journal of Cardiology 125 41-48. (doi:10.1016/j.ijcard.2007.02.027)

Slawik M, Klawitter B, Meiser E, Schories M, Zwermann O, Borm K, Peper M, Lubrich B, Hug MJ \& Nauck M 2007 Thyroid hormone replacement for central hypothyroidism: a randomized controlled trial comparing two doses of thyroxine (T4) with a combination of $\mathrm{T}_{4}$ and triiodothyronine. Journal of Clinical Endocrinology and Metabolism 92 4115-4122. (doi:10.1210/jc.2007-0297)

Stahl JH, Kendall SK, Brinkmeier ML, Greco TL, Watkins-Chow DE, Campos-Barros A, Lloyd RV \& Camper SA 1999 Thyroid hormone is essential for pituitary somatotropes and lactotropes. Endocrinology 140 1884-1892.

Sun Y, Bak B, Schoenmakers N, van Trotsenburg AS, Oostdijk W, Voshol P, Cambridge E, White JK, le Tissier P, Gharavy SN et al. 2012 Loss-offunction mutations in IGSF1 cause an X-linked syndrome of central hypothyroidism and testicular enlargement. Nature Genetics $\mathbf{4 4}$ 1375-1381. (doi:10.1038/ng.2453)

Szkudlinski MW, Fremont V, Ronin C \& Weintraub BD 2002 Thyroidstimulating hormone and thyroid-stimulating hormone receptor structure-function relationships. Physiological Reviews 82 473-502. (doi:10.1152/physrev.00031.2001)

Tajima T, Ohtake A, Hoshino M, Amemiya S, Sasaki N, Ishizu K \& Fujieda K 2009 OTX2 loss of function mutation causes anophthalmia and combined pituitary hormone deficiency with a small anterior and ectopic posterior pituitary. Journal of Clinical Endocrinology and Metabolism 94 314-319. (doi:10.1210/jc.2008-1219)

Tajima T, Nakamura A \& Ishizu K 2013 A novel mutation of IGSF1 in a Japanese patient of congenital central hypothyroidism without macroorchidism. Endocrine Journal 60 245-249. (doi:10.1507/endocrj. EJ13-0009)

Takuma N, Sheng HZ, Furuta Y, Ward JM, Sharma K, Hogan BL, Pfaff SL, Westphal H, Kimura S \& Mahon KA 1998 Formation of Rathke's pouch requires dual induction from the diencephalon. Development 125 $4835-4840$.

van Tijn DA, de Vijlder JJ \& Vulsma T 2008 Role of the thyrotropinreleasing hormone stimulation test in diagnosis of congenital central hypothyroidism in infants. Journal of Clinical Endocrinology and Metabolism 93 410-419. (doi:10.1210/jc.2006-2656)

Turton JP, Reynaud R, Mehta A, Torpiano J, Saveanu A, Woods KS, Tiulpakov A, Zdravkovic V, Hamilton J, ttard-Montalto S et al. 2005 Novel mutations within the POU1F1 gene associated with variable combined pituitary hormone deficiency. Journal of Clinical Endocrinology and Metabolism 90 4762-4770. (doi:10.1210/jc.2005-0570)

Van Tijn DA, de Vijlder JJ, Verbeeten B Jr, Verkerk PH \& Vulsma T 2005 Neonatal detection of congenital hypothyroidism of central origin. Journal of Clinical Endocrinology and Metabolism 90 3350-3359. (doi:10.1210/jc.2004-2444)

Voutetakis A, Argyropoulou M, Sertedaki A, Livadas S, Xekouki P, ManiatiChristidi M, Bossis I, Thalassinos N, Patronas N \& Dacou-Voutetakis C 2004 Pituitary magnetic resonance imaging in 15 patients with Prop1 gene mutations: pituitary enlargement may originate from the intermediate lobe. Journal of Clinical Endocrinology and Metabolism 89 2200-2206. (doi:10.1210/jc.2003-031765)

Vuissoz JM, Deladoëy J, Buyukgebiz A, Cemeroglu P, Gex G, Gallati S \& Mullis PE 2001 New autosomal recessive mutation of the TSH- $\beta$ subunit gene causing central isolated hypothyroidism. Journal of Clinical Endocrinology and Metabolism 86 4468-4471.

Wang D, Xia X, Liu Y, Oetting A, Walker RL, Zhu Y, Meltzer P, Cole PA, Shi YB \& Yen PM 2009 Negative regulation of TSH $\alpha$ target gene by thyroid hormone involves histone acetylation and corepressor complex dissociation. Molecular Endocrinology 23 600-609. (doi:10.1210/me.2008-0389)

Ward RD, Raetzman LT, Suh H, Stone BM, Nasonkin IO \& Camper SA 2005 Role of PROP1 in pituitary gland growth. Molecular Endocrinology 19 698-710. (doi:10.1210/me.2004-0341)

Ward RD, Stone BM, Raetzman LT \& Camper SA 2006 Cell proliferation and vascularization in mouse models of pituitary hormone deficiency. Molecular Endocrinology 20 1378-1390. (doi:10.1210/me.2005-0409)

Weber G, Vigone MC, Stroppa L \& Chiumello G 2003 Thyroid function and puberty. Journal of Pediatric Endocrinology and Metabolism 16(Suppl 2) 253-257.

Wondisford FE, Farr EA, Radovik S, Steinfelder HJ, Moates JM et al. 1989 Thyroid hormone inhibition of human thyrotropin $\beta$ subunit gene expression is mediated by a cis-acting element located in the first exon. Journal of Biological Chemistry 264 14601-14604.

Woods KS, Cundall M, Turton J, Rizotti K, Mehta A, Palmer R, Wong J, Chong WK, Al-Zyoud M, El-Ali M et al. 2005 Over- and underdosage of SOX3 is associated with infundibular hypoplasia and hypopituitarism. American Journal of Human Genetics 76 833-849. (doi:10.1086/430134)

Yamada M \& Mori M 2008 Mechanisms related to the pathophysiology and management of central hypothyroidism. Nature Clinical Practice. Endocrinology \& Metabolism 4 683-694. (doi:10.1038/ncpendmet0995)

Yamada M, Saga Y, Shibusawa N, Hirato J, Murakami M, Iwasaki T, Hashimoto K, Satoh T, Wakabayashi K, Taketo MM et al. 1997 Tertiary hypothyroidism and hyperglycemia in mice with targeted disruption of the thyrotropin-releasing hormone gene. PNAS 94 10862-10867. (doi:10.1073/pnas.94.20.10862)

You SH, Liao X, Weiss RE \& Lazar MA 2010 The interaction between nuclear receptor corepressor and histone deacetylase 3 regulates both positive and negative thyroid hormone action in vivo. Molecular Endocrinology 24 1359-1367. (doi:10.1210/me.2009-0501)

Zeng H, Schimpf BA, Rohde AD, Pavlova MN, Gragerov A \& Bergmann JE 2007 Thyrotropin-releasing hormone receptor 1-deficient mice display increased depression and anxiety-like behavior. Molecular Endocrinology 21 2795-2804. (doi:10.1210/me.2007-0048)

Zhu X, Gleiberman AS \& Rosenfeld MG 2007 Molecular physiology of pituitary development: signaling and transcriptional networks. Physiological Reviews 87 933-963. (doi:10.1152/physrev.00006.2006)

Zwaveling-Soonawala N, van Trotsenburg AS \& Verkerk PH 2015 The severity of congenital hypothyroidism of central origin should not be underestimated. Journal of Clinical Endocrinology and Metabolism 100 E297-E300. (doi:10.1210/jc.2014-2871)

Received in final form 17 September 2015

Accepted 28 September 2015

Accepted Preprint published online 28 September 2015 http://joe.endocrinology-journals.org

DOI: 10.1530/JOE-15-0341 (c) 2015 The authors Printed in Great Britain
Published by Bioscientifica Ltd 